Gadjah Mada International Journal of Business

May-August 2009, Vol. 11, No. 2, pp. 191-228

\title{
WHAT DRIVES THE PAYMENT OF HIGHER MERGER PREMIUMS?
}

\author{
Soegiharto
}

STIE YKPN, Yogyakarta, Indonesia

This study examines whether the premiums paid to targets firms are affected by bidder CEO overconfidence, merger waves, method of payment, industry of merged firms, and capital liquidity. Using merger data for the period spanning from 1991 to 2000, this study finds that CEOs pay less premiums in cash mergers and pay more premiums for mergers undertaken during the year of high capital liquidity. Moreover, the findings also demonstrate that CEOs tend to pay higher merger premiums for mergers that occur during merger waves and in high capital liquidity year. CEOs' behavior, which is the main variable examined in this study, does not show any significant effect on the premiums paid. This suggests that the effect of CEO overconfidence on the premiums paid may be exaggerated.

Keywords: CEO’s behavior; merger; merger waves; overconfidence; premium 
Gadjah Mada International Journal of Business, May-August 2009, Vol. 11, No. 2

\section{Introduction}

Premium is the key statement by a bidder CEO of how much extra value he or she can get from a target firm, and it underlines the bidder CEO's confidence that the target's stock price inadequately reflects the value of the firm's resources and prospects. Moreover, premium is important not only as a statement of pricing and the bidder's expectation, but also because it affects the ultimate merger performance and can materially alter firm size. A study by Roll (1986) indicates that the amount of premiums paid to targets is affected by bidders CEOs' overconfidence (hubris). His hubris hypothesis suggests bidder managers engage in mergers and acquisitions with an overly optimistic opinion of their abilities to create value, and this results in paying higher premiums to targets. In addition, the result of Hayward and Hambrick's (1997) study suggests that CEO hubris, manifested as exaggerated pride or self-confidence, plays a substantial role in the merger process, particularly in the decision of how much to pay. Other studies (e.g., Hietala et al. 2003; Morck et al. 1990; Shleifer and Vishny 1989) also indicate that bidders tend to pay higher premium to target firms, which are reflected in theirnegative stock returns during takeover announcements.

This study argues that premiums paid to target firms are affected by other key factors in addition to CEOs' behavior, such as the timing of mergers, the industry of merged firms, and the method of payment used to complete mergers. It is well documented that merger activity occurs in waves (e.g., Andrade et al. 2001; Harford 2005). During merger waves, bidder CEOs may pay higher premiums as there may be a potential competition amongst bidders. CEOs of bidders that acquire targets from a different industry may also pay higher premiums since they may overestimate the value of mergers due to their lack of experiences, capabilities, and knowledge of targets' businesses. CEOs of stock mergers may also pay higher premiums when they believe their stocks are overvalued.

The aims of this study are to examine whether there is a difference in premiums paid to target firms by overconfident and less overconfident CEOs, for mergers occurring in waves and outside the waves, for stock and cash mergers, for within and across industry mergers, and for mergers conducted in high and low liquidity years. Moreover, this study also investigates whether these five variables - CEOs' behavior, merger timing, method of payment, industry of merged firms, and capital liquidity — also lead CEOs to pay higher premiums to target firms. The findings indicate that CEOs pay less premiums in cash mergers and pay more premiums for mergers undertaken during the years of high capital liquidity. In addition, the findings also demonstrate that CEOs who undertake mergers during merger waves and through the high capital liquidity years tend to pay higher merger premiums. 
Soegiharto-What Drives the Payment of Higher Merger Premiums?

The outline of this paper is as follows. Literature review and predictions are presented in Sections 2 and 3, respectively. Section 4 describes data and methodology employed, and Section 5 presents and discusses the results of this study. Section 5 concludes the study.

\section{Literature Review}

The final price paid for a merger or acquisition, especially a large one, is determined by the top management coup in conjunction with its principal advisers (Haspeslagh and Jemison 1991). While final pricing of major mergers and acquisitions requires approval of the board of directors, boards rely heavily on guidance from top management (Mace 1971). Within the top management group, the CEO is pivotal in approving bid premiums in large mergers and acquisitions. Since large mergers and acquisitions are invariably highly visible events, require high-level negotiations, involve major corporate outlays, and can materially alter firm size and future performance, the bidder CEOs will be extensively involved (Haspeslagh and Jemison 1991). In determining the amount of merger premiums, CEOs may be affected by such factors as their behavior, merger timing, method of payment, and industry of merged firms, which are discussed in the four following subsections.

\section{CEO Overconfidence}

Roll (1986) assumes that hubris (overconfidence) stems from management's excessive self-confidence and also argues that the findings in many studies support hubris as much as any other explanations for mergers and acquisitions. Hubris management may believe that the present performance of target firm is inadequate, and that the firm's prospects will be better in their hands. Hence, higher premiums are offered to the target. As documented in the self-enhancement literature, individuals tend to overestimate their abilities when they compare themselves to their peers or unspecified benchmarks (Alicke 1985; Alicke et al. 1995; Weinstein and Klein 2002). As implied in the "better than average effect," individuals are more likely to attribute outcomes to their actions when they succeed than when they fail since they expect their behavior to generate success. In turn, this selfserving attribution of outcomes reinforces their overconfidence (Gervais and Odean 2001). As argued by Weinsten and Klein (2002) and Weinsten (1980), individuals are likely to be overconfident about events that have a positive meaning and representation to them. Particularly, Weinstein (1980) argues that individuals are more overconfident about outcomes that they believe to be under their controls. A CEO who undertakes a merger and 
Gadjah Mada International Journal of Business, May-August 2009, Vol. 11, No. 2

ostensibly substitutes the target's incumbent management with himself is likely to feel the fantasy of control over the outcome and to underestimate the likelihood of ultimate failure (Langer 1975; March and Shapira 1987). Individuals may also be especially overconfident concerning outcomes to which they are highly committed (Weinstein 1980). The CEO's current professional standing and his or her future employment prospects may considerably increase if he or she conducts a merger successfully.

A study by Hayward and Hambrick (1997) investigates the sources of CEO hubris and examines the effect of hubris on premiums paid. They find that three indicators of hubris they employ - the firm's recent success, current media praise for the CEO, and self-importance of the CEO - are highly associated with the size of premiums paid in acquisitions. They also state that exaggerated selfconfidence contributes to the overall CEO hubris. A later study by Malmendier and Tate (2003) employs particular measures as proxies for overconfidence to test the hubris hypothesis. They analyze the impact of the CEO overconfidence on mergers and acquisitions, and argue that overconfident CEOs overestimate their abilities to generate returns both in their current firms and in potential targets of takeover. They find that the market reacts negatively to takeover bids and that this effect is significantly stronger for overconfident CEOs. As bidder CEOs may have different behavior (overconfident or less overconfident) in undertaking mergers, there may be a difference in premiums paid by overconfident or less overconfident CEOs to target firms.

\section{Merger Waves}

It is well documented that merger activity occurring in waves tend to be concentrated in industries, and the industries have been different in each of the major waves identified. Previous empirical research on mergers and acquisitions has concentrated on documenting trends and characteristics of mergers. Perhaps the most consistent empirical feature found in the literature is that merger activity is strongly clustered by time and industry (e.g., Andrade et al. 2001; Harford 2005; Mitchell and Mulherin 1996; Mulherin and Boone 2000). Mitchell and Mulherin (1996) suggest that waves are driven by industry shocks that trigger restructuring and consolidation of industries. Andrade and Stafford (2004) find a strong support for the existence of both expansionary and contractionary motivations for merger activity, and also find that relatedindustry mergers follow industry shocks and occur in times of excess capacity. Mulherin and Boone (2000) confirm the industry-level clustering of mergers by finding a significant variation in takeover activity as well as in divestiture. Andrade et al. (2001) confirm the industry-level clustering of mergers by providing evidence that merger activity is strongly clustered by industry, and find deregulation as a 
Soegiharto-What Drives the Payment of Higher Merger Premiums?

key driver of merger activity. Harford's (2005) findings support a neoclassical explanation for merger waves, showing that merger waves occur in response to specific industry shocks that require large-scale reallocation of assets. His interpretation of neoclassical theory provides a plausible explanation for shocks as the driver of industry merger waves.

On the other hand, Shleifer and Vishny (2003) and Rhodes-Kropf and Viswanathan (2004) claim that waves are triggered by stock market overvaluation. Several studies, including Ang and Cheng (2003), Dong et al. (2002), and Rhodes-Kropfet al. (2004), have empirically examined market misvaluation theory. Those three studies find that the merger waves occur when market valuations are high relative to "true" valuations. In addition, Rhodes-Kropf et al. (2004) note that their results are not only consistent with the behavioral mispricing theory but also with the interpretation that merger activity spikes when growth opportunities are high or when firmspecific discount rates are low. This latter interpretation is similar to the neoclassical hypothesis with a capital liquidity component. While a large body of research has examined the determinants of merger waves, relatively little is known about how the establishment of merger premiums depends on the effects of merger waves. As mergers may or may not occur during merger waves, there may be a difference in premiums paid to targets.

\section{Industry of Merged Firms}

The issue of choice between diversification and specialization in corporate business activity has become the centre of large body of corporate finance literature for years. The empirical evidence generally suggests that the value of the sum of diversified firms is lower than that of focused firms, and that diversification destroys value. This can be explained by many studies which suggest that managing a diversified firm may be relatively more difficult than managing a focused firm and, therefore, a manager with higher ability is required (e.g., Finkelstein and Hambrick 1989; Rose and Shepard 1997).

In the context of mergers and acquisitions, however, the empirical evidence of the effect of diversifying mergers is mixed. As argued by Lang and Stulz (1994), Berger and Ofek (1995), and Comment and Jarrell (1995), during the 1980s and early 1990s, the value of diversified firms decreased. On the other hand, Matsusaka (1993) and Hubbard and Palia (1999) find the benefits of diversification for mergers during the 1960s. These two different findings suggest that the benefits of cross-industry mergers change over time. Since managing diversified firms may be relatively more complicated and require superior managerial capability, it may be somewhat difficult for bidder CEOs of one industry to estimate the values of target firms that belong to other industries and, hence, they may pay higher premiums to these targets. 
Gadjah Mada International Journal of Business, May-August 2009, Vol. 11, No. 2

\section{Method of Payment}

Several studies, e.g., Asquith and Mullins (1986), Masulis and Korwar (1986), and Mikkelson and Partch (1986), find that the average market reaction to the announcements of mergers and acquisitions financed with stocks is significantly negative. Similarly, Travlos (1987) reports empirical evidence consistent with this notion. He finds that the announcement-period average abnormal stock returns to bidders in stock mergers are significantly negative, while the corresponding bidders' performance in cash mergers is zero or positive. Moreover, some other studies, such as Servaes (1991) and Franks, Harris, and Titman(1991), also document that the use of stocks instead of cash to finance mergers by bidding firms results in significantly more negative returns to the firms. These findings are consistent with the signalling hypothesis. Particularly, it implies that the use of stocks as the method of payment contains negative information that the bidder is overvalued, and also signals to the market that the CEO of the bidding firm believes that his or her firm's stock is overvalued. This is also consistent with the argument of Myers and Majluf (1984), which indicates that the prevalence of information asymmetry between managers and shareholders may induce managers to issue stocks when they perceive them to be overvalued. In the context of acquisitions, the theory of Myers and Majluf (1984) implies that acquiring firms prefer to pay for mergers and acquisitions with stocks when they are overvalued and cash when the stocks are undervalued. As their stocks are overvalued, it is more likely for them to pay higher merger premiums.

\section{Empirical Predictions}

Roll (1986) argues that bidder CEOs are infected by hubris (overconfidence) in conducting mergers. Their overconfidence may cause them not to act for the best interest of shareholders, and they may overestimate the values of target firms, their abilities to manage the targets, or the gains/returns from mergers. In turn, their overconfidence may trigger them to pay higher premiums to target firms in order to successfully complete mergers. As reported by Bradley, Desai, and Kim (1988), in multiple-bidding contests, which are more likely to occur during merger waves, bidders may be required to pay higher premiums because of competition amongst themselves. Even if there is a single bidder present, the possibility of other bidders entering the race may cause the prospective winning bidder to pay a higher premium. Bidder CEOs may also pay higher premiums for mergers that involve bidders and targets from different industries. This may occur as bidder CEOs may have only few experiences, capabilities, and little knowledge of targets' businesses and, in turn, they may value the mergers incorrectly. 
Soegiharto-What Drives the Payment of Higher Merger Premiums?

Bidders tend to use stocks to finance mergers when they believe their stocks are overvalued. As their stocks are overvalued, they are more readily available to pay higher premiums to target firms. In addition, the bid premiums paid to the targets may be higher when capital liquidity is high. As the transaction costs are low (when the capital liquidity is high), the bidder CEOs may be more willing to pay more premiums to complete merger transactions.

CEOs with better pre-merger performance may believe that their managerial ability to run their firms successfully can be applied to firms they acquire. As they may also believe the acquired firm's prospect will be better in their hands and more benefits they can bring to the firm, the higher the premium they pay. It is also believed that CEOs with high level of free cash flows and low level of leverage will pay higher mergers premiums.

Kesner and Sebora (1994) argue that a CEO is the agent who is eventually responsible for actions on and reactions to the organization's strategy, design, performance, and environment Moreover, the CEO defines the policies and strategies of the firm for a substantial period of time. For a CEO with long tenure, the board should have already obtained almost all information needed on him or her, and the CEO should have already proven his or her skills in both good and bad times. As a result, as his or her tenure gets longer, he or she might have more control on the firm and stronger influ- ence on the board. With this power in hands, CEOs tend to act not for the interest of shareholders and may destroy the values of mergers they undertake by paying higher premiums to target firms in order to complete mergers, which may be a part of his or her organizational strategy. On the other hand, since a merger typically results in a decrease in the acquirer's stock price, it follows that CEOs with more equity or whose pays are more heavily weighted towards equity-based incentives might be less likely to make mergers and acquisitions or they may attempt not to overpay the target firms. Therefore, CEOs with high stock ownerships may have an interest aligned with that of shareholders. For this reason they may pay "fair" premiums in mergers they conduct.

Based on the arguments presented above, it is predicted that:

1. The bid premium paid by an overconfident CEO is higher than that paid by a less overconfident CEO, and the payment of this premium is also higher for in-wave merger, cross-industry merger, stock merger, and merger undertaken following a high liquidity year than for non-wave merger, within industry merger, cash merger, and merger undertaken following a low liquidity year, respectively.

2. An overconfident CEO is more likely to pay a higher premium for a merger undertaken during merger waves than that undertaken outside the waves. 
Gadjah Mada International Journal of Business, May-August 2009, Vol. 11, No. 2

3. An overconfident CEO is more likely to pay a higher premium than a less overconfident CEO for a merger undertaken during merger waves and outside the waves.

4. An overconfident CEO is more likely to undertake more mergers during merger waves than during non-merger waves.

In addition to these four predictions, the fifth prediction is that:

5. CEO overconfidence along with merger waves, stock overvaluation, higher capital liquidity, differentindustry target firms, better premerger performance, higher premerger free cash flows, lower premerger leverage, longer tenures, and lower stock ownerships lead bidder CEOs to pay higher merger premiums to target firms.

Overconfidence may cause CEOs to overestimate the values of target firms, their abilities to manage the targets, or the gains/returns from mergers. During merger waves, bidders may compete one another to take over the target firms. It is fairly difficult for bidder CEOs to value mergers correctly if they acquire the targets from differentindustries since they may have only few experiences, capabilities, and little knowledge of the targets' businesses. In addition, CEOs with longer tenures might have more control on the firms as they define the policies and strategies of their firms for a substantial period of time and have stronger influence on the board as they have already proven their skills and abilities to the board. With this power in hands, they may force the board to support them to complete mergers, which may be a part of their organizational strategy. Moreover, bidder CEOs with lower stock ownerships will be less affected by the decreases in bidder stock prices after mergers. They are more willing to complete mergers as they may get better rewards in managing bigger assets. In turn, all these together, accompanied by bidders' stock overvaluation (economic source of finance), high level of free cash flows, low level of leverage, and better pre-merger performance (which makes CEOs believe that the acquired firms' prospects will be better in their hands and more benefits can be brought to their firms) as well as high capital liquidity (low transaction costs) may lead to bidder CEOs being readily available to pay higher premiums to the targets.

The predictions formulated above are summarized in Table 1, and the empirical findings of this study, discussed in Section 3.5, are also previewed in the table. 
Soegiharto-What Drives the Payment of Higher Merger Premiums?

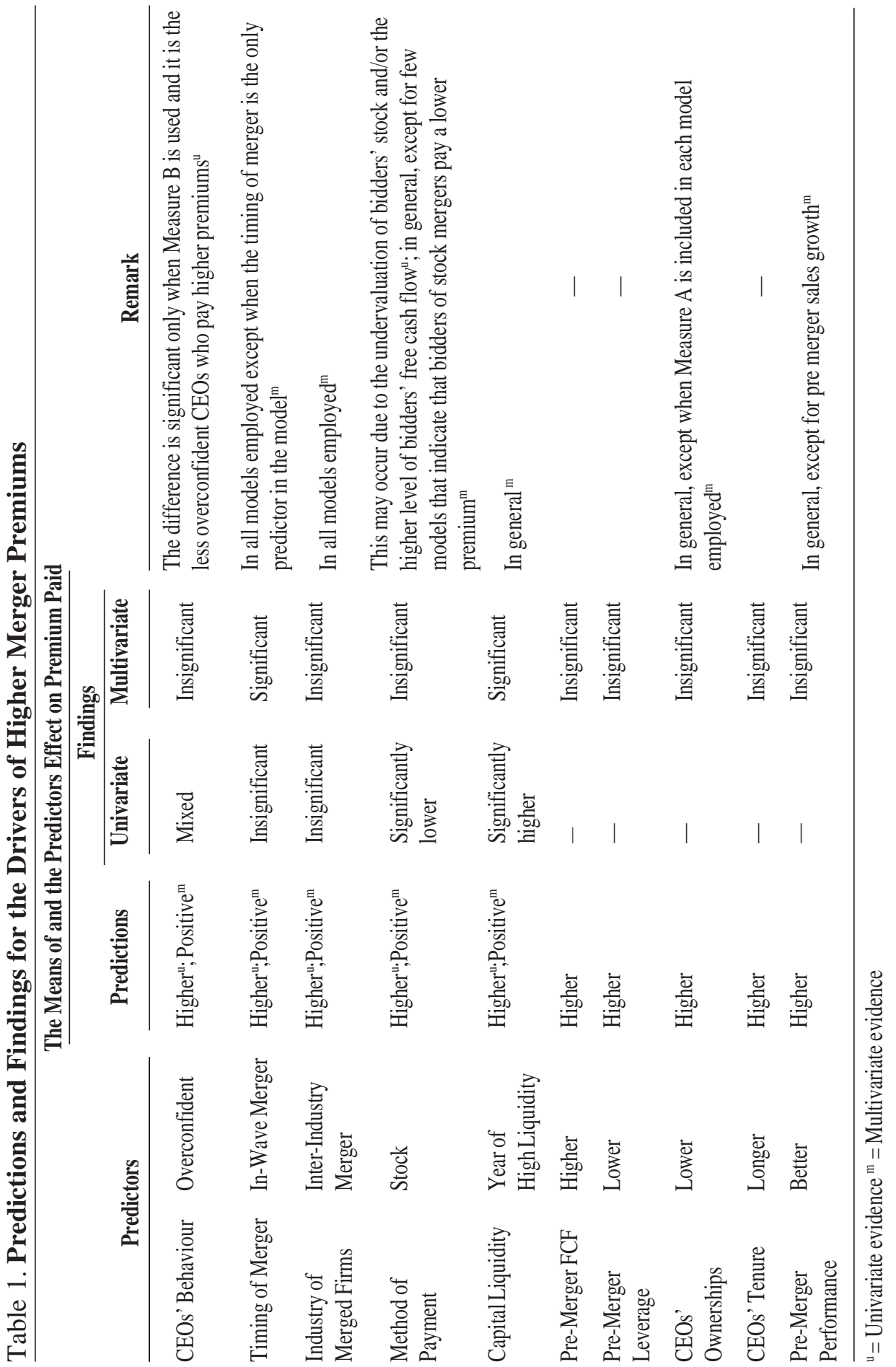


Gadjah Mada International Journal of Business, May-August 2009, Vol. 11, No. 2

\section{Data and Methodology}

\section{Data}

The data on mergers are collected from Securities Data Company's (SDC) Mergers and Acquisitions database. The data gathered include successful U.S. merger transactions that took place during the period of January 1991 to December 2000. It is required that both the bidders and the target firms be publicly traded, the form of the deal be merger, and the attitude of the deal be friendly. In addition, the transaction value has to be at least USD60 million in 2005 dollars. These criteria result in an initial sample of 3,184 mergers. The financial and stock price data for merged companies are extracted from Standard and Poor's COMPUSTAT research tape (COMPUSTAT) and Centre for Research in Securities Price (CRSP) database, respectively. All sample firms are required to be listed on these two databases. This requirement reduces the sample size to 729 mergers. Furthermore, the data for sample CEOs are collected from Execucomp database. The database provides comprehensive information on various aspects of CEOs such as the dates they are appointed to be CEOs, option packages including expiration dates and exercise prices, and CEOs' share ownerships. Nevertheless, as the information regarding options held by CEOs until year of expiration-used to measure CEOs' behavior-in this database is available only for a small number of CEOs in the sample of this study, the sample size drops to 294 mergers.

\section{Measure of Overconfidence}

A study by Malmendier and Tate (2003) collects sample of CEOs from Hall and Liebman's data. The study classifies CEOs as overconfident when they hold their stock options until the last year before expiration. Different from Malmendier and Tate (2003), this study uses Execucomp database and since information regarding options held by CEOs until year of expiration in this database is available only for a small number of CEOs in the sample of this study, it is not possible to apply their method. For this reason, this study proposes several measures of CEOs' behavior measured prior to the year of merger announcement. As these measures of CEOs' behavior are measured prior to merger announcement, they may better reflect CEO overconfidence in undertaking mergers. These measures are (Execucomp's access item presented in italic) the followings:

1. Measure 1. CEO's behavior is measured as soptexsh/(soptexsh + uexnumex). Soptexsh is the number of stock options exercised by CEOs and uexnumex is the number of unexercised vested stock options. The behavior of CEOs is classified as overconfident (less overconfident) if the percentage of options they exercise is smaller (greater) than both the annual average percentage and industry-year average percentage. 
2. Measure 2. CEO's behavior is measured using the number of shares they own (shrown). CEOs are classified as overconfident if the number of shares they own increase at the end of the year, irrespective of whether or not they exercise their options. On the other hand, if the number of shares they own at the end of the year decrease or remain unchanged, they are classified as less overconfident CEOs.

3. Measure 3. CEO's behavior is measured using the number of options exercised (soptexsh) and the number of shares owned by CEO (shrown). CEOs are classified as overconfident if they exercise no options and the number of share they own increase at the end of the year. In contrast, CEOs are classified as less overconfident if they exercise their options and the number of share they own decrease.

4. Measure 4. CEO's behavior is measured using the number of shares owned by CEO (shrown), net average value realized from exercising options (soptexer/soptexsh), and the average value the CEOs would have realized at year end if they had exercised all of their vested options that had an exercise price below the market price (inmonex/uexnumex). Soptexer is the net value realized from exercising options, and inmonex is the value that CEOs would have realized if they had exercised all of their in-the-money vested options. CEOs are classified as overconfident (less over- confident) if the number of shares they own (shrown) increase (decrease or remain unchanged) at the end of the year and inmonex/ uexnumex is greater (smaller) than soptexer/soptexsh.

5. Measure 5. CEO's behavior is measured using net average value realized from exercising options (soptexer/soptexsh) and the average value the CEOs would have realized at year end if they had exercised all of their vested options that had an exercise price below the market price (inmonex/uexnumex). Different from Measure 4, the increase of the number of shares owned by CEOs (shrown) is disregarded in this measure. CEOs are classified as overconfident (less overconfident) if inmonex/ uexnumex is greater (smaller) than soptexer/soptexsh.

\section{Identification of Merger Wave}

Soegiharto (2008) followed Harford's (2005) simulation procedure to identify merger waves. The procedure is implemented as follows. Each bidder and target is sorted into one of 48 industry groups, based on their respective SIC codes (as per Fama 1997) at the time of the bid announcement. Bidders and targets from industries are assigned to their own industries. For each industry, the highest concentration of completed merger bids involving firms in that industry within a 24month period (overlap) —as per Mitchell and Mulherin (1996) — is identified and tagged as a potential 
wave. To confirm a potential wave as an actual wave, the following simulation procedure is followed to construct a distribution of merger concentrations that facilitates the testing of the economic significance of each merger wave concentration. The total number of merger bids for a given industry over the 120-month sample period (i.e., 10 years $\mathrm{x} 12$ months) is identified. Each bid is then randomly assigned to one of the 120 months with the probability of assignment being 1/120 for each month. This is repeated 1,000 times. Then, the highest concentration of merger activity within a 24-month period from each of the 1,000 draws is calculated. The actual concentration of activity from the potential wave is compared to the empirical distribution based on the simulated data. If the actual peak concentration exceeds the $95^{\text {th }}$ percentile from that empirical distribution, that period is coded as a wave. The final result of the merger simulation in the study of Soegiharto (2008) is 28 waves. He indicates that the average number of bids during the 24-month wave period over the 10year sampling period is 53 whereas the average number of bids during the 24month non-wave period is 14.3 . This present study employs the identical waves identified in the study of Soegiharto (2008).

\section{Measure of Bid Premium}

Similar to Raj and Forsyth (2003), Hayward and Hambrick (1997), and Crawford and Lechner (1996), the acquisition premium is calculated over the period in which target stock price is not affected by information on the merger. In this study, the window begins 30 trading days before the first announcement of the takeover and ends when the offer is accepted by the target shareholders. Bid premiums are calculated as: (bid offer - target price $_{-30}$ )/ target price ${ }_{-30}$. Bid offer is the final price paid per target share by the bidder and target price ${ }_{-30}$ is the value of the target share 30 days prior to the first bid announcement.

\section{Results}

\section{Univariate Tests}

Prior to examining the research predictions, this study tests the associations amongst the measures of overconfidence proposed. Using the chisquare test, it is found that more than one measure are associated with the other measures, except for Measure 1 which has no association with Measure 2 (Pearson statistic $=0.012$, significance $=0.911$ ), and for Measure 2 which has no association with Measure 5 (Pearson statistic $=0.888$, significance $=0.346$ ). Measure 1 , Measure 2, and Measure 5 are selected and employed as measures of CEOs' behavior in this study. Even though there is an association between Measure 1 and Measure 5, these two measures are selected and employed because their association is fairly weak as indicated by the value of contingency coefficient of 0.380 and significance of 0.001 in the symmetric measure. Measures 
Soegiharto-What Drives the Payment of Higher Merger Premiums?

1,2 , and 5 employed are renamed as Measure A, Measure B, and Measure $\mathrm{C}$, respectively.

\section{The Difference in Premiums Paid}

The first prediction of this study is that the premiums paid by overconfident CEOs are higher than those paid by less overconfident CEOs. To test this prediction, CEOs are classified as overconfident and less overconfident CEOs, and the independent sample $t$ test is used to look at the difference in the means of the premiums paid by these two different groups of CEOs. The results of the test, as presented in Table 2, indicate that there is a difference in the average premiums paid by the two groups of CEOs. However, the difference is only significant when Measure B is used as a measure of CEOs' behavior and it is the less overconfident CEOs who pay the higher premiums. These results, therefore, do not substantiate Prediction 1 . The overconfident CEOs paying less premiums may be due to their confidence that they value the targets correctly and the conviction of target stockholders that their firms will be better/superior in the hands of these overconfident CEOs.

Irrespective of whether CEOs are overconfident or less overconfident, this study also tests the difference in the means of bid premiums paid for mergers that occur during merger waves (in-wave mergers) and outside the waves (non-wave mergers), mergers that involve bidders and targets from the same industry (intra-industry mergers) and different industries (interindustry mergers), mergers completed using stocks and cash, and mergers undertaken during the years of low and high (capital) liquidity. A high liquidity year is the year in which the

Table 2. The Difference in the Means of Premiums Paid by Overconfident and Less Overconfident CEOs

CEOs’ behavior is measured using Measure A, Measure B, and Measure C.

\begin{tabular}{|c|c|c|c|c|c|c|c|c|}
\hline \multirow[b]{2}{*}{ Measures } & \multirow[b]{2}{*}{ CEO's Behavior } & \multicolumn{7}{|c|}{ Premium Paid } \\
\hline & & $\mathbf{N}$ & Mean & SD & $\begin{array}{c}\text { SE } \\
\text { Mean }\end{array}$ & $\begin{array}{c}\text { Mean } \\
\text { Diff. }\end{array}$ & $\begin{array}{c}\text { SE } \\
\text { Diff. }\end{array}$ & $\begin{array}{c}\text { Sig. } \\
\text { (2-tailed) }\end{array}$ \\
\hline \multirow{2}{*}{ A } & Less overconfident & 84 & 0.487 & 0.297 & 0.032 & \multirow[t]{2}{*}{0.027} & \multirow[t]{2}{*}{0.041} & \multirow[t]{2}{*}{0.508} \\
\hline & Overconfident & 145 & 0.460 & 0.302 & 0.025 & & & \\
\hline \multirow{2}{*}{ B } & Less overconfident & 81 & 0.549 & 0.301 & 0.033 & \multirow{2}{*}{0.119} & \multirow{2}{*}{0.039} & \multirow{2}{*}{0.002} \\
\hline & Overconfident & 179 & 0.430 & 0.282 & 0.021 & & & \\
\hline \multirow{2}{*}{$\mathrm{C}$} & Less overconfident & 132 & 0.493 & 0.300 & 0.026 & \multirow{2}{*}{0.046} & \multirow{2}{*}{0.037} & \multirow{2}{*}{0.208} \\
\hline & Overconfident & 129 & 0.446 & 0.291 & 0.026 & & & \\
\hline
\end{tabular}


Gadjah Mada International Journal of Business, May-August 2009, Vol. 11, No. 2

rate spread is below its time-series median and the industry's market-tobook ratio is simultaneously above its time-series median. Low liquidity year is all other year.

It can be predicted that as merger competition during merger waves may be potentially tighter, the premiums paid to target firms during these waves may be higher. The premiums paid to the targets may also be higher in the interindustry (across industry) mergers because bidder CEOs may have only few experiences and little knowledge about targets' businesses and, in turn, they may overestimate the values of the targets. Many studies suggest that managing a diversified firm may be a relatively more difficult task than managing a focused firm and, there- fore, a CEO of higher ability is required (Finkelstein and Hambrick 1989; Rose and Shepard 1997). Bidders tend to use stocks to finance mergers when they believe their stocks are overvalued. As their stocks are overvalued, they are more readily available to pay higher premium to targets. In addition, the bid premiums paid to the targets may be higher when capital liquidity is high. As the transaction costs are low when the capital liquidity is high, the bidder CEOs may be more willing to pay more premiums to complete merger transactions.

The results of the independent sample $t$-test for these predictions (see Table 3) indicate that there are no differences in the means of bid premiums paid for mergers undertaken dur-

Table 3. The Difference in the Means of Premiums Paid for Mergers that Occur During Merger Waves and Outside The Waves

Mergers that involve bidder and target firms from the same and different industry, mergers completed using cash and stock, and mergers undertaken during a low and high (capital) liquidity year

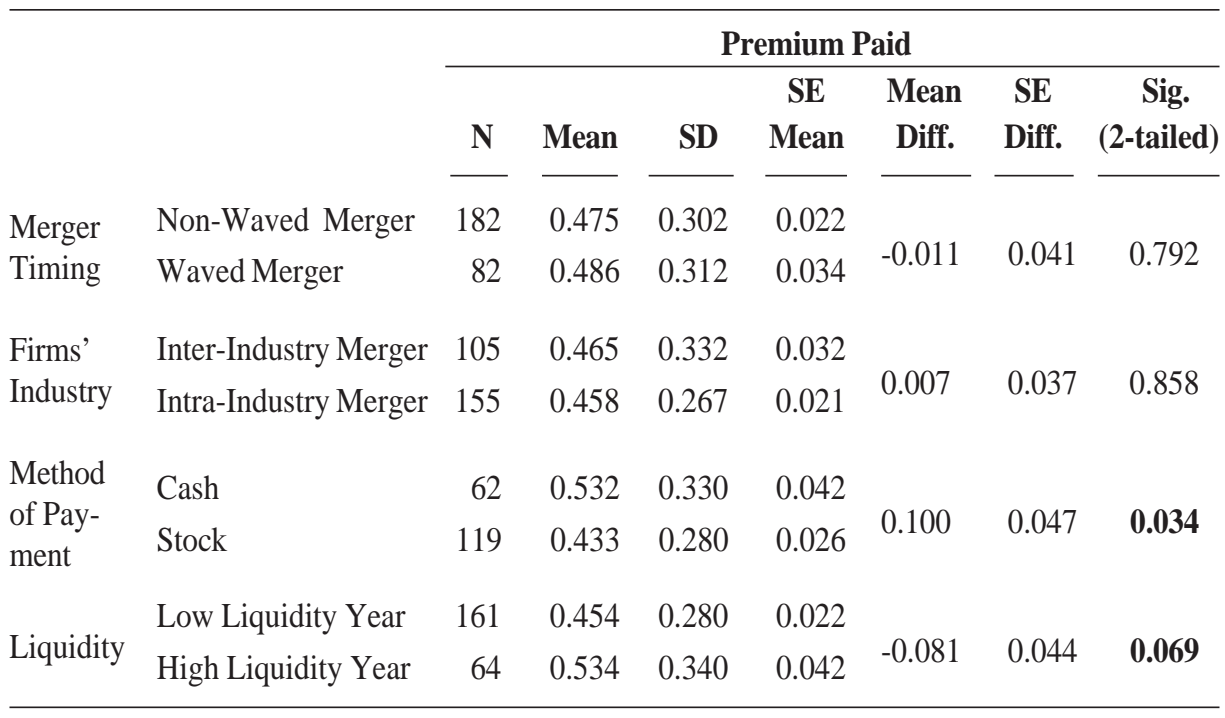


Soegiharto-What Drives the Payment of Higher Merger Premiums?

ing merger waves and outside the waves and for mergers that involve bidders and targets from the same and different industries. On the other hand, the findings document that the means of premiums paid for stock mergers are significantly lower than those for cash mergers. This may occur due to the undervaluation of bidders' stocks and/ or the high level of their free cash flows. In addition, the means of premiums paid for mergers undertaking following a high liquidity year are significantly higher (at significant level of 0.1) than those for mergers conducted following a low liquidity year. These results suggest that bidders will pay higher premiums when they have access to economic sources of fund to accommodate the reallocation of assets.

To test the second prediction that overconfident CEOs are more likely to pay higher premiums for in-wave mergers than for non-wave mergers, overconfident CEOs are classified into: (1) overconfident CEOs who undertake mergers during merger waves and (2) those who undertake mergers outside the waves. The independent sample $t$ test is employed to test the difference in the means of premiums paid by these two groups of overconfident CEOs. As presented in Panel A of Table 4, the results indicate that the premiums paid by overconfident CEOs for mergers undertaken during merger waves and outside the waves are not significantly different. Hence, these findings do not support Prediction 2. The presence of many target firms during merger waves may provide an opportunity for overconfident bidder CEOs to choose the most favorable one without paying higher premiums. For comparison, this study also conducts an identical independent sample t-test for less overconfident CEOs. The results of the test, as presented in Panel B of Table 4, are similar to those presented in Panel A, i.e., the premiums paid by less overconfident CEOs for in-wave mergers and non-wave mergers are not significantly different.

The third prediction is that overconfident CEOs are more likely to pay higher premiums relative to those paid by less overconfident CEOs for mergers undertaken during merger waves and outside the waves. To test this conjecture, this study classifies mergers into in-wave mergers and non-wave mergers. The independent sample $t$ test is used to look at the difference in the means of premiums paid by the overconfident CEOs and the less overconfident CEOs for mergers that occur during the waves. As presented in Panel $\mathrm{C}$ of Table 3, the results indicate that the premiums paid by the overconfident CEOs and the less overconfident CEOs during merger waves are not significantly different. For mergers that occur outside the waves (see Panel D), the results imply that there are differences in the means of premiums paid by the overconfident CEOs and the less overconfident CEOs, except when Measure A is used as a measure of CEOs' behavior. The result of this $t$ test indicates that the premiums paid by the less overconfident CEOs for 
Gadjah Mada International Journal of Business, May-August 2009, Vol. 11, No. 2

Table 4. The Difference in The Means of Premiums Paid by Overconfident CEOs for In-Wave and Non-Wave Mergers

(Panel A)

CEOs' behaviour is measured using Measure A, Measure B, and Measure C

\begin{tabular}{|c|c|c|c|c|c|c|c|c|}
\hline \multirow[b]{2}{*}{ Measure } & \multirow[b]{2}{*}{$\begin{array}{l}\text { Overconfident CEOs- } \\
\text { Merger Timing }\end{array}$} & \multicolumn{7}{|c|}{ Premium Paid } \\
\hline & & $\mathrm{N}$ & Mean & SD & $\begin{array}{c}\text { SE } \\
\text { Mean }\end{array}$ & $\begin{array}{l}\text { Mean } \\
\text { Diff. }\end{array}$ & $\begin{array}{l}\text { SE } \\
\text { Diff. }\end{array}$ & $\begin{array}{c}\text { Sig. } \\
\text { (2-tailed) }\end{array}$ \\
\hline \multirow[t]{2}{*}{ A } & Overconfident CEOs-Non-Wave Mergers & 105 & 0.447 & 0.276 & 0.027 & \multirow[t]{2}{*}{-0.028} & \multirow{2}{*}{0.056} & \multirow{2}{*}{0.620} \\
\hline & Overconfident CEOs-In-Wave Mergers & 39 & 0.475 & 0.346 & 0.055 & & & \\
\hline \multirow{2}{*}{ B } & Overconfident CEOs-Non-Wave Mergers & 123 & 0.422 & 0.272 & 0.025 & \multirow{2}{*}{-0.040} & \multirow{2}{*}{0.046} & \multirow{2}{*}{0.391} \\
\hline & Overconfident CEOs-In-Wave Mergers & 57 & 0.461 & 0.318 & 0.042 & & & \\
\hline \multirow{2}{*}{$\mathrm{C}$} & Overconfident CEOs-Non-Wave Mergers & 89 & 0.429 & 0.279 & 0.030 & \multirow[t]{2}{*}{-0.073} & \multirow[t]{2}{*}{0.056} & \multirow[t]{2}{*}{0.194} \\
\hline & Overconfident CEOs-In-Wave Mergers & 41 & 0.502 & 0.332 & 0.052 & & & \\
\hline
\end{tabular}

(Panel B)

The difference in the means of premium paid by less overconfident CEOs for in-wave and non-wave mergers CEOs' behaviour is measured using Measure A, Measure B, and Measure C.

\begin{tabular}{|c|c|c|c|c|c|c|c|c|}
\hline \multirow[b]{2}{*}{ Measure } & \multirow[b]{2}{*}{$\begin{array}{l}\text { Less Overconfident CEOs- } \\
\text { Merger Timing }\end{array}$} & \multicolumn{7}{|c|}{ Premium Paid } \\
\hline & & $\mathbf{N}$ & Mean & SD & $\begin{array}{c}\text { SE } \\
\text { Mean }\end{array}$ & $\begin{array}{l}\text { Mean } \\
\text { Diff. }\end{array}$ & $\begin{array}{l}\text { SE } \\
\text { Diff. }\end{array}$ & $\begin{array}{c}\text { Sig. } \\
\text { (2-tailed) }\end{array}$ \\
\hline \multirow{3}{*}{ A } & $\begin{array}{l}\text { Less Overconfident CEOs-Non-Wave } \\
\text { Mergers }\end{array}$ & 74 & 0.484 & 0.305 & 0.036 & & & \\
\hline & Less Overconfident CEOs-In-Wave & & & & & -0.012 & 0.057 & 0.837 \\
\hline & Mergers & 43 & 0.496 & 0.281 & 0.043 & & & \\
\hline \multirow[b]{2}{*}{ B } & $\begin{array}{l}\text { Less Overconfident CEOs-Non-Wave } \\
\text { Mergers }\end{array}$ & 56 & 0.552 & 0.306 & 0.041 & & & \\
\hline & $\begin{array}{l}\text { Less Overconfident CEOs-In-Wave } \\
\text { Mergers }\end{array}$ & 25 & 0.542 & 0.298 & 0.060 & 0.010 & 0.073 & 0.887 \\
\hline \multirow{2}{*}{$\mathrm{C}$} & $\begin{array}{l}\text { Less Overconfident CEOs-Non-Wave } \\
\text { Mergers }\end{array}$ & 91 & 0.503 & 0.303 & 0.032 & & & \\
\hline & $\begin{array}{l}\text { Less Overconfident CEOs-In-Wave } \\
\text { Mergers }\end{array}$ & 41 & 0.469 & 0.295 & 0.046 & 0.034 & 0.057 & 0.552 \\
\hline
\end{tabular}


Soegiharto-What Drives the Payment of Higher Merger Premiums?

\section{Continued from Table 4}

(Panel C)

The difference in premium paid by overconfident CEOs and less overconfident CEOs for in-wave mergers CEOs' behaviour is measured using Measure A, Measure B, and Measure C.

\begin{tabular}{|c|c|c|c|c|c|c|c|c|}
\hline \multirow[b]{2}{*}{ Measure } & \multirow[b]{2}{*}{$\begin{array}{c}\text { Less Overconfident CEOs- } \\
\text { Merger Timing }\end{array}$} & \multicolumn{7}{|c|}{ Premium Paid } \\
\hline & & $\mathbf{N}$ & Mean & SD & $\begin{array}{c}\text { SE } \\
\text { Mean }\end{array}$ & $\begin{array}{l}\text { Mean } \\
\text { Diff. }\end{array}$ & $\begin{array}{l}\text { SE } \\
\text { Diff. }\end{array}$ & $\begin{array}{c}\text { Sig. } \\
\text { (2-tailed) }\end{array}$ \\
\hline \multirow{2}{*}{ A } & Less Overconfident CEOs & 43 & 0.496 & 0.281 & 0.043 & \multirow{2}{*}{0.021} & \multirow{2}{*}{0.069} & \multirow{2}{*}{0.766} \\
\hline & Overconfident CEOs & 39 & 0.475 & 0.346 & 0.055 & & & \\
\hline \multirow{2}{*}{ B } & Less Overconfident CEOs & 25 & 0.542 & 0.298 & 0.060 & \multirow{2}{*}{0.081} & \multirow{2}{*}{0.075} & \multirow{2}{*}{0.284} \\
\hline & Overconfident CEOs & 57 & 0.461 & 0.318 & 0.042 & & & \\
\hline \multirow{2}{*}{ C } & Less Overconfident CEOs & 41 & 0.469 & 0.295 & 0.046 & \multirow{2}{*}{-0.033} & \multirow{2}{*}{0.069} & \multirow{2}{*}{0.636} \\
\hline & Overconfident CEOs & 41 & 0.502 & 0.332 & 0.052 & & & \\
\hline
\end{tabular}

(Panel D)

The difference in premium paid by overconfident CEOs and less overconfident CEOs for non-wave mergers. CEOs' behaviour is measured using Measure A, Measure B, and Measure C.

\begin{tabular}{|c|c|c|c|c|c|c|c|c|}
\hline \multirow[b]{2}{*}{ Measure } & \multirow[b]{2}{*}{$\begin{array}{l}\text { Less Overconfident CEOs- } \\
\text { Merger Timing }\end{array}$} & \multicolumn{7}{|c|}{ Premium Paid } \\
\hline & & $\mathrm{N}$ & Mean & SD & $\begin{array}{c}\text { SE } \\
\text { Mean }\end{array}$ & $\begin{array}{l}\text { Mean } \\
\text { Diff. }\end{array}$ & $\begin{array}{l}\text { SE } \\
\text { Diff. }\end{array}$ & $\begin{array}{c}\text { Sig. } \\
\text { (2-tailed) }\end{array}$ \\
\hline A & $\begin{array}{l}\text { Less Overconfident CEOs } \\
\text { Overconfident CEOs }\end{array}$ & $\begin{array}{r}74 \\
105\end{array}$ & $\begin{array}{l}0.484 \\
0.447\end{array}$ & $\begin{array}{l}0.305 \\
0.276\end{array}$ & $\begin{array}{l}0.036 \\
0.027\end{array}$ & 0.021 & 0.069 & 0.766 \\
\hline B & $\begin{array}{l}\text { Less Overconfident CEOs } \\
\text { Overconfident CEOs }\end{array}$ & $\begin{array}{r}56 \\
123\end{array}$ & $\begin{array}{l}0.552 \\
0.422\end{array}$ & $\begin{array}{l}0.306 \\
0.272\end{array}$ & $\begin{array}{l}0.041 \\
0.025\end{array}$ & 0.037 & 0.044 & 0.403 \\
\hline $\mathrm{C}$ & $\begin{array}{l}\text { Less Overconfident CEOs } \\
\text { Overconfident CEOs }\end{array}$ & $\begin{array}{l}91 \\
89\end{array}$ & $\begin{array}{l}0.503 \\
0.429\end{array}$ & $\begin{array}{l}0.303 \\
0.279\end{array}$ & $\begin{array}{l}0.032 \\
0.030\end{array}$ & 0.074 & 0.043 & 0.091 \\
\hline
\end{tabular}

non-wave mergers arehigher than those paid by the overconfident CEOs. These findings do not support Prediction 3, but they are consistent with the finding in Prediction 1, particularly when Measure B is used as the measure of CEO overconfidence, that less overconfident CEOs pay higher premiums. 
Gadjah Mada International Journal of Business, May-August 2009, Vol. 11, No. 2

\section{CEO's Behavior and the Timing of Mergers}

This study also predicts that an overconfident CEO is more likely to undertake more mergers during merger waves than outside the waves (Prediction 4). To test this prediction, CEOs are classified into overconfident CEOs and less overconfident CEOs, and mergers are categorized into in-wave mergers and non-wave mergers. The chi-square test is employed to test the relatedness between these two variables.

The results of the test, when Measure A is utilized, indicate a Pearson statistic of 6.388 and a significance of 0.012. By examining the percentage within the CEOs' Behavior (Measure $A$ is used) cell in the cross-tabulations presented in Table 5, it can be concluded that the portion of mergers undertaken outside merger waves by overconfident CEOs (73.8\%) is greater than that undertaken outside merger waves by less overconfident CEOs (58.8\%). It can also be concluded that the portion of overconfident CEOs who undertake mergers outside merger waves $(68.0 \%)$ is greater than that undertaking mergers during the waves (51.8\%). These conclusions are supported by the result of the hypothesis test for two proportions that indicates $Z$ value of 2.518 and $p$ value of 0.005 . In addition, the value of contingency coefficient on the symmetric measure is 0.158 with a significance of 0.012 , which suggests that there is a relationship between CEOs' behavior and the timing of mergers even though this rela- tionship is very weak. In contrast to these results, the chi-square test for the relatedness between CEOs' behavior - measured using either measure $\mathrm{B}$ or Measure $\mathrm{C}$ - and the timing of mergers indicates an insignificant association between these two variables (cross-tabulations are not presented). This suggests that either overconfident CEOs or less overconfident CEOs do not have time preference in undertaking mergers (during merger waves or outside the waves). Overall, these findings do not support Prediction 4.

\section{Multivariate Tests}

\section{Variables Affecting the Premiums Paid to Target Firms}

CEOs' behavior, pre-merger performance, pre-merger free cash flows, pre-merger leverage, method of payment, capital liquidity, industry of merged firms, timing of mergers, CEO tenure, and CEO stock ownerships are variables that may affect the premiums paid by CEOs in merger transactions (Prediction 5). CEOs' behavior is a dummy variable that takes the value of one for an overconfident CEO and zero for a less overconfident CEO, and pre-merger performance includes net income to sales, assets turnover, return on assets, sales growth, and market-to-book ratios. Free cash flow is calculated as: operating income (taxes + interest + preferred dividend + common dividend); while leverage is calculated as long-term debt divided by book value of equity. Capital li- 
Soegiharto-What Drives the Payment of Higher Merger Premiums?

Table 5. The Association between CEOs’ Behavior and Timing of Mergers

\begin{tabular}{|c|c|c|c|c|c|}
\hline & & & \multicolumn{2}{|c|}{$\begin{array}{l}\text { CEOs' Behaviour } \\
\text { (Measure A) }\end{array}$} & \multirow[b]{2}{*}{ Total } \\
\hline & & & $\begin{array}{c}\text { Less } \\
\text { Over- } \\
\text { confident }\end{array}$ & $\begin{array}{l}\text { Over- } \\
\text { confident }\end{array}$ & \\
\hline & \multirow{5}{*}{$\begin{array}{l}\text { Non-Wave } \\
\text { Merger }\end{array}$} & Count & 57.0 & 121.0 & 178.0 \\
\hline M & & Expected Count & 66.2 & 111.8 & 178.0 \\
\hline e & & \% within Merger Timing & $32.0 \%$ & $68.0 \%$ & $100.0 \%$ \\
\hline $\begin{array}{l}\text { g } \\
\text { e }\end{array}$ & & $\begin{array}{l}\text { \% within CEOs' Behaviour } \\
\text { (Measure A) }\end{array}$ & $58.8 \%$ & $73.8 \%$ & $68.2 \%$ \\
\hline r & & $\%$ of Total & $21.8 \%$ & $46.4 \%$ & $68.2 \%$ \\
\hline $\mathrm{T}$ & \multirow{5}{*}{$\begin{array}{l}\text { In-Wave } \\
\text { Merger }\end{array}$} & Count & 40.0 & 43.0 & 83.00 \\
\hline $\mathrm{i}$ & & Expected Count & 30.8 & 52.2 & 83.0 \\
\hline $\mathrm{m}$ & & \% within Merger Timing & $48.2 \%$ & $51.8 \%$ & $100.0 \%$ \\
\hline $\begin{array}{l}\mathrm{n} \\
\mathrm{g}\end{array}$ & & $\begin{array}{l}\text { \% within CEOs’ Behaviour } \\
\text { (Measure A) }\end{array}$ & $41.2 \%$ & $26.2 \%$ & $31.8 \%$ \\
\hline & & $\%$ of Total & $15.3 \%$ & $16.5 \%$ & $31.8 \%$ \\
\hline & \multirow{5}{*}{ Total } & Count & 97.0 & 164.0 & 261.0 \\
\hline & & Expected Count & 97.0 & 164.0 & 261.0 \\
\hline & & \% within Merger Timing & $37.2 \%$ & $62.8 \%$ & $100.0 \%$ \\
\hline & & $\begin{array}{l}\text { \% within CEOs' Behaviour } \\
\text { (Measure A) }\end{array}$ & $100.0 \%$ & $100.0 \%$ & $100.0 \%$ \\
\hline & & $\%$ of Total & $37.2 \%$ & $62.8 \%$ & $100.0 \%$ \\
\hline
\end{tabular}


Gadjah Mada International Journal of Business, May-August 2009, Vol. 11, No. 2

quidity is also a dummy variable that takes the value of one for year with high liquidity and zero otherwise. A high liquidity year is the year in which the rate spread is below its time-series median and the industry's market-tobook ratio is simultaneously above its time-series median. Low liquidity year is all other year. Three other dummy variables are: (1) industry of merged firms that takes the value of one for mergers involving bidders and targets from the same industry (intra-industry merger) and zero for mergers involving bidders and targets form different industries (interindustry merger); (2) merger timing that takes the value of one for mergers that occur during the waves (in-wave mergers) and zero for those that occur outside the waves (non-wave mergers); and (3) the method of payment that takes the value of one for stocks and zero for cash. The difference between the date an individual becomes a CEO and the date the merger announced is used to determine CEO tenure, and shares owned by a CEO is divided by the number of shares outstanding to obtain CEO stock ownership. To test the effects of these variables on premiums paid to the target firms, this study employs regression analysis and as in the univariate analysis, three measures of CEOs behavior - Measure A, Measure B, and Measure C - are also used.

The individual effects of 16 predictors on the amount of premiums paid to target firms are examined. Of the 16 regression models employed, only three predictors can explain the amount of premiums paid. These three predictors can be seen in Models 1, 2, and 7 of Table 6 (the results of regression analyses for the 16 models used are presented in Appendix A).

The method of payment in Model 1 and the behavior of bidder CEOs measured using Measure B in Model 7 have a significant and negative effect on the premiums paid to target firms. This suggests that bidders which pay mergers with stocks or have overconfident CEOs tend to pay lower amount of premiums to the targets. The bidder of stock mergers may pay lower premiums due to the undervaluation of their stocks and/or the high level of their free cash flows whereas the overconfident CEOs may pay less premiums due to their confidence that they value the targets correctly and the belief of target stockholders that their firms will be better/superior in the hands of these overconfident bidder CEOs. These results are consistent with those of univariate tests presented in Table 3 and Table 2 (Measure B). Capital liquidity (see Model 2 in Table 6 ) is the other independent variable that also significantly affects the dependent variable (at level of significance of 0.1 ). This result suggests that during the year of high liquidity, bidders are more likely to pay higher premiums to the target firms. It may occur as bidders have access to economic sources of fund to accommodate the reallocation of assets. This result is also consistent with that of univariate tests presented in Table 3. 


\title{
Soegiharto—-What Drives the Payment of Higher Merger Premiums?
}

\section{Table 6. Predicting Premiums Paid to Target Firms}

\begin{abstract}
Regression analyses are used to predict premiums paid to target firms. Bid premiums are calculated as: (bid offer - target price ${ }_{30}$ )/target price $_{-30}$. Bid offer is the final price paid per target share by the bidder and target price ${ }_{-30}$ is the value of the target shares thirty days prior to the first bid announcement. The explanatory variables employed are free cash flows, leverage, CEOs tenure, and CEOs stock ownerships. Free cash flow is calculated as operating income - (taxes + interest + preferred dividend + common dividend) and leverage is calculated as long-term debt divided by book value of equities. The difference between the date an individual became a CEO and the date the mergers announced is used to determine CEOs' tenure, and shares owned by CEOs is divided by number of shares outstanding to obtain CEOs' stock ownerships. The measure of performance used as predictors are net income to sales, assets turnover, return on assets, sales growth, and market-to-book. Five other explanatory variable are dummies. These variables are method of payment that takes value of 1 for stock and 0 for cash, capital liquidity that takes value of 1 for high liquidity years (the years in which the rate spread is below its time-series median and the industry's market-to-book ratio is simultaneously above its time-series median) and 0 for low liquidity year (all other years), timing of merger that takes value of 1 for in-wave mergers and 0 for non-wave mergers, industry of merged firms that takes value of 1 for intraindustry mergers and 0 for inter-industry mergers, and CEOs behavior that takes value of 1 for overconfident CEOs and 0 for less overconfident CEOs. Three measures of CEOs' behavior, Measure A, Measure B, and Measure C, are used in Model A, Model B, and Model C, respectively.
\end{abstract}

\begin{tabular}{|c|c|c|c|c|c|c|c|c|c|c|c|c|c|}
\hline & \multicolumn{7}{|c|}{ Without Measure of CE0s' Behaviour } & \multicolumn{6}{|c|}{ With Measure A (Model A) } \\
\hline & 1 & 2 & 3 & 4 & 5 & 6 & 7 & A1 & A2 & A3 & A4 & A5 & A6 \\
\hline Intercept & $\begin{array}{c}0.532 \\
{[0.000]}\end{array}$ & $\begin{array}{c}0.454 \\
{[0.000]}\end{array}$ & $\begin{array}{c}0.506 \\
{[0.000]}\end{array}$ & $\begin{array}{c}0.482 \\
{[0.000]}\end{array}$ & $\begin{array}{c}0.400 \\
{[0.000]}\end{array}$ & $\begin{array}{c}0.357 \\
{[0.000]}\end{array}$ & $\begin{array}{c}0.549 \\
{[0.000]}\end{array}$ & $\begin{array}{c}0.529 \\
{[0.000]}\end{array}$ & $\begin{array}{c}0.500 \\
{[0.000]}\end{array}$ & $\begin{array}{c}0.539 \\
{[0.000]}\end{array}$ & $\begin{array}{c}0.498 \\
{[0.000]}\end{array}$ & $\begin{array}{c}0.381 \\
{[0.000]}\end{array}$ & $\begin{array}{c}0.323 \\
{[0.005]}\end{array}$ \\
\hline Pre-merger FCF & & & & $\begin{array}{c}0.000 \\
{[0.464]}\end{array}$ & $\begin{array}{c}0.000 \\
{[0.575]}\end{array}$ & $\begin{array}{c}0.000 \\
{[0.608]}\end{array}$ & & & & & $\begin{array}{c}0.000 \\
{[0.425]}\end{array}$ & $\begin{array}{c}0.000 \\
{[0.650]}\end{array}$ & $\begin{array}{c}0.000 \\
{[0.316]}\end{array}$ \\
\hline Pre-merger Leverage & & & & $\begin{array}{c}-0.111 \\
{[0.345]}\end{array}$ & $\begin{array}{l}-0.085 \\
{[0.454]}\end{array}$ & $\begin{array}{c}-0.070 \\
{[0.547]}\end{array}$ & & & & & $\begin{array}{c}-0.099 \\
{[0.438]}\end{array}$ & $\begin{array}{c}-0.090 \\
{[0.471]}\end{array}$ & $\begin{array}{c}-0.140 \\
{[0.264]}\end{array}$ \\
\hline Method of Payment & $\begin{array}{c}-0.100 \\
{[0.034]}\end{array}$ & & $\begin{array}{r}-0.099 \\
{[0.047]}\end{array}$ & $\begin{array}{c}-0.021 \\
{[0.753]}\end{array}$ & $\begin{array}{l}-0.074 \\
{[0.278]}\end{array}$ & $\begin{array}{c}-0.076 \\
{[0.282]}\end{array}$ & & $\begin{array}{c}-0.078 \\
{[0.127]}\end{array}$ & & $\begin{array}{c}-0.087 \\
{[0.132]}\end{array}$ & $\begin{array}{c}0.002 \\
{[0.976]}\end{array}$ & $\begin{array}{c}-0.069 \\
{[0.386]}\end{array}$ & $\begin{array}{c}-0.074 \\
{[0.343]}\end{array}$ \\
\hline Capital Liquidity & & $\begin{array}{c}0.081 \\
{[0.069]}\end{array}$ & $\begin{array}{c}0.129 \\
{[0.031]}\end{array}$ & $\begin{array}{c}0.155 \\
{[0.059]}\end{array}$ & $\begin{array}{c}0.169 \\
{[0.037]}\end{array}$ & $\begin{array}{c}0.176 \\
{[0.040]}\end{array}$ & & & $\begin{array}{c}0.069 \\
{[0.147]}\end{array}$ & $\begin{array}{c}0.160 \\
{[0.021]}\end{array}$ & $\begin{array}{c}0.146 \\
{[0.102]}\end{array}$ & $\begin{array}{c}0.165 \\
{[0.070]}\end{array}$ & $\begin{array}{c}0.202 \\
{[0.027]}\end{array}$ \\
\hline Timing of Mergers & & & & & $\begin{array}{c}0.187 \\
{[0.012]}\end{array}$ & $\begin{array}{c}0.199 \\
{[0.010]}\end{array}$ & & & & & & $\begin{array}{c}0.186 \\
{[0.048]}\end{array}$ & $\begin{array}{c}0.225 \\
{[0.020]}\end{array}$ \\
\hline Firms Industry & & & & & $\begin{array}{c}0.101 \\
{[0.146]}\end{array}$ & $\begin{array}{c}0.110 \\
{[0.144]}\end{array}$ & & & & & & $\begin{array}{c}0.117 \\
{[0.145]}\end{array}$ & $\begin{array}{c}0.095 \\
{[0.233]}\end{array}$ \\
\hline CEOs' Tenure & & & & & & $\begin{array}{c}-0.005 \\
{[0.633]}\end{array}$ & & & & & & & $\begin{array}{c}0.071 \\
{[0.026]}\end{array}$ \\
\hline CEOs' Ownerships & & & & & & $\begin{array}{c}0.000 \\
{[0.472]}\end{array}$ & & & & & & & $\begin{array}{c}0.000 \\
{[0.812]}\end{array}$ \\
\hline CEOs' Behavior & & & & & & & & $\begin{array}{c}-0.019 \\
{[0.700]}\end{array}$ & $\begin{array}{l}-0.088 \\
{[0.045]}\end{array}$ & $\begin{array}{c}-0.070 \\
{[0.213]}\end{array}$ & $\begin{array}{c}-0.061 \\
{[0.400]}\end{array}$ & $\begin{array}{c}0.019 \\
{[0.813]}\end{array}$ & $\begin{array}{c}0.011 \\
{[0.892]}\end{array}$ \\
\hline CEOs’ Behaviour & & & & & & & $\begin{array}{c}-0.119 \\
{[0.002]}\end{array}$ & & & & & & \\
\hline \multicolumn{14}{|l|}{ CEOs' Behaviour } \\
\hline Adjusted $R^{2}$ & 0.019 & 0.010 & 0.044 & 0.010 & 0.088 & 0.083 & 0.032 & 0.003 & 0.020 & 0.047 & -0.004 & 0.056 & 0.109 \\
\hline SE of the Estimate & 0.298 & 0.298 & 0.294 & 0.300 & 0.288 & 0.292 & 0.288 & 0.303 & 0.290 & 0.319 & 0.312 & 0.303 & 0.296 \\
\hline$p$-value for F-test & 0.034 & 0.069 & 0.012 & 0.307 & 0.036 & 0.066 & 0.002 & 0.286 & 0.054 & 0.025 & 0.464 & 0.142 & 0.052 \\
\hline Number of obs. & 180 & 224 & 153 & 86 & 86 & 83 & 259 & 157 & 193 & 136 & 75 & 75 & 74 \\
\hline
\end{tabular}


Gadjah Mada International Journal of Business, May-August 2009, Vol. 11, No. 2

\section{Continued from Table 6}

\begin{tabular}{|c|c|c|c|c|c|c|c|c|c|c|c|c|}
\hline & \multicolumn{6}{|c|}{ Without Measure of CEOs' Behaviour } & \multicolumn{6}{|c|}{ With Measure A (Model A) } \\
\hline & 8 & 9 & 10 & 11 & 12 & 13 & A8 & A9 & A10 & A11 & A12 & A13 \\
\hline Intercept & $\begin{array}{l}0.430 \\
0.000]\end{array}$ & $\begin{array}{c}0.340 \\
{[0.000]}\end{array}$ & $\begin{array}{c}0.369 \\
{[0.000]}\end{array}$ & $\begin{array}{c}0.356 \\
{[0.000]}\end{array}$ & $\begin{array}{c}0.367 \\
{[0.000]}\end{array}$ & $\begin{array}{c}0.415 \\
{[0.000]}\end{array}$ & $\begin{array}{c}0.396 \\
{[0.001]}\end{array}$ & $\begin{array}{c}0.319 \\
{[0.006]}\end{array}$ & $\begin{array}{c}0.339 \\
{[0.004]}\end{array}$ & $\begin{array}{c}0.331 \\
{[0.004]}\end{array}$ & $\begin{array}{c}0.362 \\
{[0.002]}\end{array}$ & $\begin{array}{c}0.410 \\
{[0.001]}\end{array}$ \\
\hline Pre-merger FCF & $\begin{array}{c}0.000 \\
{[0.789]}\end{array}$ & $\begin{array}{c}0.000 \\
{[0.603]}\end{array}$ & $\begin{array}{c}0.000 \\
{[0.576]}\end{array}$ & $\begin{array}{c}0.000 \\
{[0.661]}\end{array}$ & $\begin{array}{c}0.000 \\
{[0.512]}\end{array}$ & $\begin{array}{c}0.000 \\
{[0.693]}\end{array}$ & $\begin{array}{c}0.000 \\
{[0.459]}\end{array}$ & $\begin{array}{c}0.000 \\
{[0.332]}\end{array}$ & $\begin{array}{c}0.000 \\
{[0.299]}\end{array}$ & $\begin{array}{c}0.000 \\
{[0.402]}\end{array}$ & $\begin{array}{c}0.000 \\
{[0.235]}\end{array}$ & $\begin{array}{c}0.000 \\
{[0.171]}\end{array}$ \\
\hline Pre-merger Leverage & $\begin{array}{c}-0.069 \\
{[0.554]}\end{array}$ & $\begin{array}{c}-0.054 \\
{[0.645]}\end{array}$ & $\begin{array}{c}-0.087 \\
{[0.468]}\end{array}$ & $\begin{array}{c}-0.068 \\
{[0.562]}\end{array}$ & $\begin{array}{c}-0.066 \\
{[0.574]}\end{array}$ & $\begin{array}{c}-0.038 \\
{[0.768]}\end{array}$ & $\begin{array}{c}-0.128 \\
{[0.304]}\end{array}$ & $\begin{array}{c}-0.134 \\
{[0.293]}\end{array}$ & $\begin{array}{c}-0.154 \\
{[0.226]}\end{array}$ & $\begin{array}{c}-0.136 \\
{[0.284]}\end{array}$ & $\begin{array}{c}-0.133 \\
{[0.287]}\end{array}$ & $\begin{array}{c}-0.197 \\
{[0.182]}\end{array}$ \\
\hline Method of Payment & $\begin{array}{c}-0.104 \\
{[0.154]}\end{array}$ & $\begin{array}{c}-0.088 \\
{[0.224]}\end{array}$ & $\begin{array}{c}-0.075 \\
{[0.292]}\end{array}$ & $\begin{array}{c}-0.098 \\
{[0.184]}\end{array}$ & $\begin{array}{c}-0.069 \\
{[0.345]}\end{array}$ & $\begin{array}{c}-0.109 \\
{[0.161]}\end{array}$ & $\begin{array}{c}-0.093 \\
{[0.252]}\end{array}$ & $\begin{array}{c}-0.078 \\
{[0.324]}\end{array}$ & $\begin{array}{c}-0.069 \\
{[0.378]}\end{array}$ & $\begin{array}{c}-0.092 \\
{[0.255]}\end{array}$ & $\begin{array}{c}-0.061 \\
{[0.439]}\end{array}$ & $\begin{array}{c}-0.062 \\
{[0.479]}\end{array}$ \\
\hline Capital Liquidity & $\begin{array}{c}0.169 \\
{[0.058]}\end{array}$ & $\begin{array}{c}0.167 \\
{[0.053]}\end{array}$ & $\begin{array}{c}0.164 \\
{[0.062]}\end{array}$ & $\begin{array}{c}0.183 \\
{[0.037]}\end{array}$ & $\begin{array}{c}0.153 \\
{[0.082]}\end{array}$ & $\begin{array}{c}0.137 \\
{[0.153]}\end{array}$ & $\begin{array}{c}0.185 \\
{[0.056]}\end{array}$ & $\begin{array}{c}0.196 \\
{[0.035]}\end{array}$ & $\begin{array}{c}0.186 \\
{[0.048]}\end{array}$ & $\begin{array}{c}0.207 \\
{[0.028]}\end{array}$ & $\begin{array}{c}0.165 \\
{[0.078]}\end{array}$ & $\begin{array}{c}0.167 \\
{[0.119]}\end{array}$ \\
\hline Timing of Mergers & $\begin{array}{c}0.194 \\
{[0.016]}\end{array}$ & $\begin{array}{c}0.198 \\
{[0.011]}\end{array}$ & $\begin{array}{c}0.220 \\
{[0.009]}\end{array}$ & $\begin{array}{c}0.190 \\
{[0.021]}\end{array}$ & $\begin{array}{c}0.200 \\
{[0.019]}\end{array}$ & $\begin{array}{c}0.180 \\
{[0.046]}\end{array}$ & $\begin{array}{c}0.217 \\
{[0.024]}\end{array}$ & $\begin{array}{c}0.220 \\
{[0.025]}\end{array}$ & $\begin{array}{c}0.239 \\
{[0.016]}\end{array}$ & $\begin{array}{c}0.210 \\
{[0.041]}\end{array}$ & $\begin{array}{c}0.192 \\
{[0.066]}\end{array}$ & $\begin{array}{c}0.204 \\
{[0.078]}\end{array}$ \\
\hline Firms Industry & $\begin{array}{c}0.128 \\
{[0.095]}\end{array}$ & $\begin{array}{c}0.122 \\
{[0.109]}\end{array}$ & $\begin{array}{c}0.112 \\
{[0.139]}\end{array}$ & $\begin{array}{c}0.122 \\
{[0.113]}\end{array}$ & $\begin{array}{c}0.116 \\
{[0.130]}\end{array}$ & $\begin{array}{c}0.122 \\
{[0.141]}\end{array}$ & $\begin{array}{c}0.114 \\
{[0.157]}\end{array}$ & $\begin{array}{c}0.101 \\
{[0.220]}\end{array}$ & $\begin{array}{c}0.097 \\
{[0.225]}\end{array}$ & $\begin{array}{c}0.104 \\
{[0.199]}\end{array}$ & $\begin{array}{c}0.095 \\
{[0.238]}\end{array}$ & $\begin{array}{c}0.071 \\
{[0.428]}\end{array}$ \\
\hline CEOs' Tenure & $\begin{array}{c}0.000 \\
{[0.549]}\end{array}$ & $\begin{array}{c}0.000 \\
{[0.387]}\end{array}$ & $\begin{array}{c}0.000 \\
{[0.440]}\end{array}$ & $\begin{array}{c}0.000 \\
{[0.538]}\end{array}$ & $\begin{array}{c}0.000 \\
{[0.523]}\end{array}$ & $\begin{array}{c}0.000 \\
{[0.569]}\end{array}$ & $\begin{array}{c}0.000 \\
{[0.809]}\end{array}$ & $\begin{array}{c}0.000 \\
{[0.878]}\end{array}$ & $\begin{array}{c}0.000 \\
{[0.879]}\end{array}$ & $\begin{array}{c}0.000 \\
{[0.796]}\end{array}$ & $\begin{array}{c}0.000 \\
{[0.695]}\end{array}$ & $\begin{array}{c}0.000 \\
{[0.363]}\end{array}$ \\
\hline CEOs' Ownerships & $\begin{array}{c}-0.014 \\
{[0.274]}\end{array}$ & $\begin{array}{c}-0.006 \\
{[0.551]}\end{array}$ & $\begin{array}{c}-0.006 \\
{[0.611]}\end{array}$ & $\begin{array}{c}-0.007 \\
{[0.570]}\end{array}$ & $\begin{array}{c}-0.003 \\
{[0.803]}\end{array}$ & $\begin{array}{c}-0.012 \\
{[0.396]}\end{array}$ & $\begin{array}{c}0.055 \\
{[0.087]}\end{array}$ & $\begin{array}{c}0.068 \\
{[0.040]}\end{array}$ & $\begin{array}{c}0.067 \\
{[0.042]}\end{array}$ & $\begin{array}{c}0.067 \\
{[0.041]}\end{array}$ & $\begin{array}{c}0.074 \\
{[0.021]}\end{array}$ & $\begin{array}{c}0.074 \\
{[0.052]}\end{array}$ \\
\hline Pre-merger NI/Sales & $\begin{array}{c}-0.480 \\
{[0.125]}\end{array}$ & & & & & $\begin{array}{c}-0.464 \\
{[0.265]}\end{array}$ & $\begin{array}{c}-0.541 \\
{[0.119]}\end{array}$ & & & & & $\begin{array}{c}-0.396 \\
{[0.389]}\end{array}$ \\
\hline Pre-merger ATO & & $\begin{array}{c}0.049 \\
{[0.359]}\end{array}$ & & & & $\begin{array}{c}-0.015 \\
{[0.832]}\end{array}$ & & $\begin{array}{c}0.020 \\
{[0.743]}\end{array}$ & & & & $\begin{array}{c}-0.038 \\
{[0.664]}\end{array}$ \\
\hline Pre-merger ROA & & & $\begin{array}{c}-0.169 \\
{[0.422]}\end{array}$ & & & $\begin{array}{c}0.252 \\
{[0.474]}\end{array}$ & & & $\begin{array}{c}-0.165 \\
{[0.478]}\end{array}$ & & & $\begin{array}{c}-0.169 \\
{[0.683]}\end{array}$ \\
\hline Pre-merger Sales Growth & & & & $\begin{array}{c}0.131 \\
{[0.291]}\end{array}$ & & $\begin{array}{c}0.058 \\
{[0.728]}\end{array}$ & & & & $\begin{array}{c}0.104 \\
{[0.444]}\end{array}$ & & $\begin{array}{c}0.399 \\
{[0.080]}\end{array}$ \\
\hline Pre-merger M/B & & & & & $\begin{array}{c}-0.015 \\
{[0.425]}\end{array}$ & $\begin{array}{c}-0.015 \\
{[0.483]}\end{array}$ & & & & & $\begin{array}{c}-0.012 \\
{[0.537]}\end{array}$ & $\begin{array}{c}-0.006 \\
{[0.780]}\end{array}$ \\
\hline CEOs' Behaviour & & & & & & & $\begin{array}{c}0.011 \\
{[0.893]}\end{array}$ & $\begin{array}{c}0.010 \\
{[0.906]}\end{array}$ & $\begin{array}{c}0.006 \\
{[0.942]}\end{array}$ & $\begin{array}{c}0.003 \\
{[0.970]}\end{array}$ & $\begin{array}{c}-0.026 \\
{[0.757]}\end{array}$ & $\begin{array}{c}-0.014 \\
{[0.879]}\end{array}$ \\
\hline Adjusted $R^{2}$ & 0.102 & 0.081 & 0.078 & 0.094 & 0.042 & 0.007 & 0.129 & 0.097 & 0.103 & 0.113 & 0.071 & 0.052 \\
\hline SE of the Estimate & 0.290 & 0.292 & 0.294 & 0.294 & 0.293 & 0.296 & 0.292 & 0.298 & 0.297 & 0.298 & 0.295 & 0.297 \\
\hline$p$-value for F-test & 0.050 & 0.080 & 0.089 & 0.06 & 0.206 & 0.426 & 0.043 & 0.079 & 0.070 & 0.059 & 0.140 & 0.263 \\
\hline Number of observation & 79 & 83 & 82 & 80 & 81 & 76 & 71 & 74 & 74 & 72 & 73 & 67 \\
\hline
\end{tabular}


Soegiharto-What Drives the Payment of Higher Merger Premiums?

\section{Continued from Table 6}

\begin{tabular}{|c|c|c|c|c|c|c|c|c|c|c|c|c|}
\hline & \multicolumn{6}{|c|}{ With Measure B (Model B) } & \multicolumn{6}{|c|}{ With Measure C (Model C) } \\
\hline & B1 & B2 & B3 & B4 & B5 & B6 & $\mathrm{C} 1$ & $\mathrm{C} 2$ & $\mathrm{C} 3$ & $\mathrm{C} 4$ & $\mathrm{C} 5$ & C6 \\
\hline Intercept & $\begin{array}{c}0.582 \\
{[0.000]}\end{array}$ & $\begin{array}{c}0.535 \\
{[0.000]}\end{array}$ & $\begin{array}{c}0.565 \\
{[0.000]}\end{array}$ & $\begin{array}{c}0.479 \\
{[0.000]}\end{array}$ & $\begin{array}{c}0.393 \\
{[0.000]}\end{array}$ & $\begin{array}{c}0.330 \\
{[0.002]}\end{array}$ & $\begin{array}{c}0.538 \\
{[0.000]}\end{array}$ & $\begin{array}{c}0.485 \\
{[0.000]}\end{array}$ & $\begin{array}{c}0.523 \\
{[0.000]}\end{array}$ & $\begin{array}{c}0.522 \\
{[0.000]}\end{array}$ & $\begin{array}{c}0.433 \\
{[0.000]}\end{array}$ & $\begin{array}{c}0.389 \\
{[0.000]}\end{array}$ \\
\hline Pre-merger FCF & & & & $\begin{array}{c}0.000 \\
{[0.470]}\end{array}$ & $\begin{array}{c}0.000 \\
{[0.583]}\end{array}$ & $\begin{array}{c}0.000 \\
{[0.627]}\end{array}$ & & & & $\begin{array}{c}0.000 \\
{[0.459]}\end{array}$ & $\begin{array}{c}0.000 \\
{[0.571]}\end{array}$ & $\begin{array}{c}0.000 \\
{[0.648]}\end{array}$ \\
\hline Pre-merger Leverage & & & & $\begin{array}{l}-0.113 \\
{[0.350]}\end{array}$ & $\begin{array}{l}-0.089 \\
{[0.445]}\end{array}$ & $\begin{array}{c}-0.082 \\
{[0.491]}\end{array}$ & & & & $\begin{array}{l}-0.100 \\
{[0.390]}\end{array}$ & $\begin{array}{c}-0.079 \\
{[0.483]}\end{array}$ & $\begin{array}{l}-0.068 \\
{[0.558]}\end{array}$ \\
\hline Method of Payment & $\begin{array}{c}-0.066 \\
{[0.148]}\end{array}$ & & $\begin{array}{c}-0.086 \\
{[0.098]}\end{array}$ & $\begin{array}{c}-0.021 \\
{[0.754]}\end{array}$ & $\begin{array}{c}-0.074 \\
{[0.281]}\end{array}$ & $\begin{array}{c}-0.077 \\
{[0.282]}\end{array}$ & $\begin{array}{c}-0.089 \\
{[0.058]}\end{array}$ & & $\begin{array}{l}-0.095 \\
{[0.070]}\end{array}$ & $\begin{array}{c}-0.008 \\
{[0.906]}\end{array}$ & $\begin{array}{c}-0.061 \\
{[0.371]}\end{array}$ & $\begin{array}{c}-0.064 \\
{[0.371]}\end{array}$ \\
\hline Capital Liquidity & & $\begin{array}{c}0.057 \\
{[0.191]}\end{array}$ & $\begin{array}{c}0.143 \\
{[0.020]}\end{array}$ & $\begin{array}{c}0.156 \\
{[0.061]}\end{array}$ & $\begin{array}{c}0.171 \\
{[0.038]}\end{array}$ & $\begin{array}{c}0.183 \\
{[0.035]}\end{array}$ & & $\begin{array}{c}0.062 \\
{[0.158]}\end{array}$ & $\begin{array}{c}0.146 \\
{[0.019]}\end{array}$ & $\begin{array}{c}0.159 \\
{[0.051]}\end{array}$ & $\begin{array}{c}0.170 \\
{[0.036]}\end{array}$ & $\begin{array}{c}0.172 \\
{[0.044]}\end{array}$ \\
\hline Timing of Mergers & & & & & $\begin{array}{c}0.188 \\
{[0.012]}\end{array}$ & $\begin{array}{c}0.204 \\
{[0.009]}\end{array}$ & & & & & $\begin{array}{c}0.171 \\
{[0.022]}\end{array}$ & $\begin{array}{c}0.181 \\
{[0.022]}\end{array}$ \\
\hline Firms Industry & & & & & $\begin{array}{c}0.100 \\
{[0.152]}\end{array}$ & $\begin{array}{c}0.107 \\
{[0.157]}\end{array}$ & & & & & $\begin{array}{c}0.098 \\
{[0.154]}\end{array}$ & $\begin{array}{c}0.108 \\
{[0.151]}\end{array}$ \\
\hline CEOs' Tenure & & & & & & $\begin{array}{c}-0.005 \\
{[0.588]}\end{array}$ & & & & & & $\begin{array}{c}-0.006 \\
{[0.562]}\end{array}$ \\
\hline CEOs' Ownerships & & & & & & $\begin{array}{c}0.000 \\
{[0.426]}\end{array}$ & & & & & & $\begin{array}{c}0.000 \\
{[0.380]}\end{array}$ \\
\hline CEOs' Behaviour & & & & & & & & & & & & \\
\hline CEOs' Behaviour & $\begin{array}{l}-0.115 \\
{[0.014]}\end{array}$ & $\begin{array}{c}-0.114 \\
{[0.007]}\end{array}$ & $\begin{array}{c}-0.099 \\
{[0.062]}\end{array}$ & $\begin{array}{c}0.005 \\
{[0.937]}\end{array}$ & $\begin{array}{c}0.012 \\
{[0.857]}\end{array}$ & $\begin{array}{c}0.040 \\
{[0.576]}\end{array}$ & & & & & & \\
\hline CEOs' Behaviour & & & & & & & $\begin{array}{l}-0.031 \\
{[0.479}\end{array}$ & $\begin{array}{c}-0.060 \\
{[0.129]}\end{array}$ & $\begin{array}{c}-0.040 \\
{[0.422]}\end{array}$ & $\begin{array}{c}-0.104 \\
{[0.110]}\end{array}$ & $\begin{array}{c}-0.074 \\
{[0.243]}\end{array}$ & $\begin{array}{c}-0.074 \\
{[0.272]}\end{array}$ \\
\hline Adjusted $R^{2}$ & 0.038 & 0.034 & 0.062 & -0.002 & 0.077 & 0.075 & 0.012 & 0.013 & 0.044 & 0.029 & 0.092 & 0.086 \\
\hline SE of the Estimate & 0.286 & 0.291 & 0.306 & 0.301 & 0.289 & 0.293 & 0.294 & 0.294 & 0.309 & 0.297 & 0.287 & 0.291 \\
\hline$p$-value for F-test & 0.013 & 0.008 & 0.005 & 0.442 & 0.062 & 0.094 & 0.132 & 0.091 & 0.020 & 0.192 & 0.039 & 0.070 \\
\hline Number of obs. & 178 & 223 & 156 & 86 & 86 & 83 & 179 & 223 & 156 & 86 & 86 & 83 \\
\hline
\end{tabular}


Gadjah Mada International Journal of Business, May-August 2009, Vol. 11, No. 2

Continued from Table 6

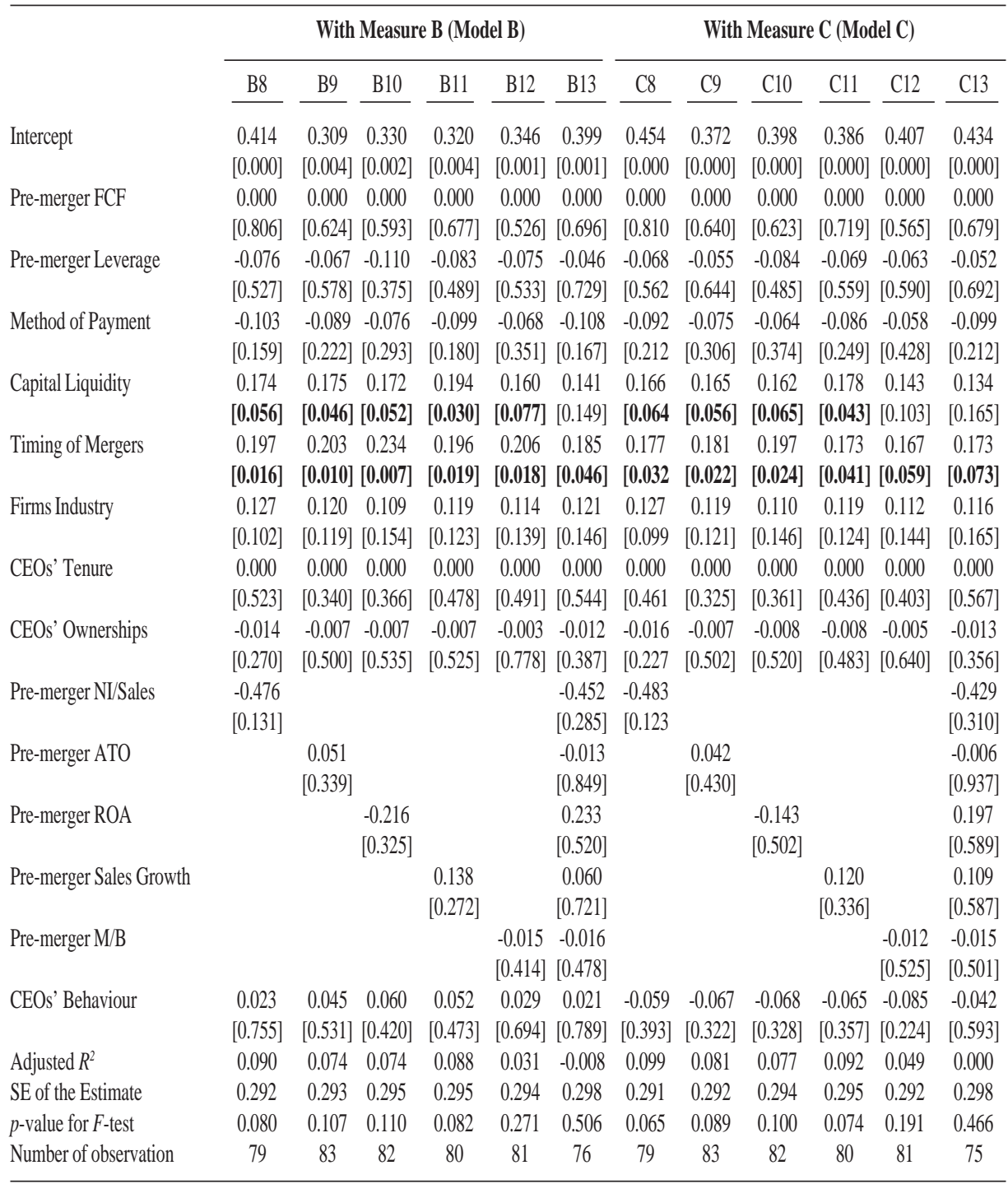


Soegiharto-What Drives the Payment of Higher Merger Premiums?

In the next analysis, this study adds each of CEOs' behavior measures (Measure A, Measure B, and Measure $C$ ) into each of the other individual explanatory variables employed. Regression models that include Measure A, Measure B, or Measure C as one of their explanatory variables are identified as Model A, Model B, or Model C, respectively, and are also presented in Table 6. Except for the results in Model C1 which show a significant (at significance level of 0.1 ) and negative effect of payment method on the dependent variable (in line with Model 1), the results of regression analyses in Model A1 and Model B1 indicate that the method of payment no longer has a significant effect on the dependent variable. Similarly, in Model A2, Model B2, and Model C2, the results also demonstrate that the effect of capital liquidity on premiums paid is no longer significant. The insignificant effects of the payment method and the capital liquidity on premiums paid are inconsistent with their effects shown in Model 1 and Model 2, respectively. Nevertheless, in Model A2, Model B1, and Model B2, the CEOs' behavior has a significant and negative effect on premiums paid to target firms, meaning that the overconfident CEOs tend to pay lower mergers premium, which is consistent with the findings in Model 7 when Measure B is used. All of regression models that comprise each of the measures of CEOs' behavior and each of the other individual explanatory variables are presented in Appendix 3-B.
As the next step, this study classifies the first eight of explanatory variables presented in Table 6 into four groups. The first group is called accounting number factors, which consist of pre-merger free cash flows and pre-merger leverage. The second group consisting of the method of payment used and the capital liquidity is labelled as financing factors. The third group, which comprises the timing of mergers and the industry of merged firms, and the fourth group comprised of CEO turnover and COE ownership are identified as merger factors and CEO factors, respectively. As presented in Table 6, the method of payment and the capital liquidity significantly affect premiums paid(see Model $3)$. The effect of the former variable is negative, suggesting that firms which finance their mergers using stocks tend to pay lower premiums. Meanwhile, the effect of the latter variable is positive, implying that during the high liquidity year the bidders are more likely to pay higher premiums. These results are consistent with those in Model 1 and Model 2 (Table 6).

In Model A3, when Measure A is added to financing factors group, the results indicate that the capital liquidity remains a significant variable but the method of payment is no longer significant. In Model B3, when Measure B is incorporated to the financing factors group, both the method of payment and the capital liquidity remain to be significantly affecting the dependent variable. Similar results also appear in Model C3 when Measure C is 
Gadjah Mada International Journal of Business, May-August 2009, Vol. 11, No. 2

included to the financing factors group. In model B3, besides the method of payment and the capital liquidity, the CEOs' behavior (Measure B) also significantly affects the premiums paid. Nevertheless, the effect of the method of payment in Model B3 and Model C3 and the effect of the CEOs' behavior in Model B3 are only marginally significant (at significance level of 0.1). All of the other results of regression analyses for the models that contain accounting number factors, financing factors, merger factors, and/or CEO factors are presented in Appendix 3-C.

Model 4, Model A4, Model B4, and Model C4 in Table 6 consist of pre-merger free cash flows, pre-merger leverage, method of payment, and capital liquidity (accounting number factors and financing factors) as explanatory variables. In addition, Model A4, Model B4, and Model C4 also contain Measure A, Measure B, and Measure $\mathrm{C}$, respectively, as the other independent variables. Except for Model A4 where there is no single predictor that significantly affects the dependent variable, the results of regression analyses for the other three models indicate that the capital liquidity is the only variable that remains to be significantly (at significance level of 0.1 ) and positively affecting the premiums paid.

Model 5, which consists of accounting number factors (pre-merger free cash flows and pre-merger leverage), financing factors (method of payment and capital liquidity), and merger factors (timing of mergers and industry of merged firms), indicates that capital liquidity remains a significant explanatory variable and that the timing of mergers appears to be a variable that significantly and positively affect the premiums paid. The results show that during merger waves, premium paid to target firms tend to be higher. Similar results can also be seen in Model A5, Model B5, and Model C5, where the measure of CEOs' behavior as the other explanatory variable is added. The results for Models 6, A6, B6, and C6 are consistent with those for Model 5. The only exception is in Model A6 where CEO tenure also has a significant and positive effect on the premiums paid.

In general, the results in Models 3, A3, B3, and C3 indicate that the method of payment is the variable that significantly and negatively affects the premiums paid and that liquidity is also the variable that significantly and positively affects the dependent variable. In addition, the results in Models 4, 5, 6, A4, A5, and A6, Models B4, B5, and B6, and Models C4, C5, and C6 indicate that liquidity is a variable that remains to be significantly and positively affecting the premiums paid and that the method of payment is no longer a variable that significantly affects the premiums paid. The results of these models also demonstrate that the timing of mergers becomes a variable that significantly and positively affects the premium paid. These results suggest that bidders will pay higher premiums when they have access to economic sources of fund to accommodate the reallocation of assets and 
Soegiharto-What Drives the Payment of Higher Merger Premiums?

there is a potential competition amongst bidders during merger waves. As a conclusion, it can be said that bidders that undertake mergers following the year of high liquidity and during merger waves tend to pay higher premiums, supporting the predictions formulated. In addition, the behavior of CEOs, in general, does not have any effect on the premiums paid to target firms.

In the next analysis, each of the pre-merger performance used in this study is individually and simultaneously added to Model 6, Model A6, Model B6, and Model C6 in Table 6, and these new models are presented in the second part of Table 6. Similar to Harford (2005), this study employs a set of measures of operating performance that consist of net income [A172] to sales [A12], assets turnover (sales [A12]/average of total assets [A6]), return on assets (operating income [A13]/average of total assets [A6]), sales [A12] growth, and market [A24xA25] to book [A60]. The premerger operating performance is the average of years -3 to -1 relative to the announcement industry-adjusted performance. In general (at significance level of $0.01,0.05$, and 0.1 ), the results of regression analyses show that the capital liquidity and the timing of mergers remain to be significantly and positively affecting the premiums paid (Model 8 to Model 12, Model A8 to Model A12, Model B8 to Model B12, and Model C8 to Model C12). These are consistent with the results pre- sented in Models 5, 6, A5, and A6, Models B5 and B6, and Models C5 and C6. In full models (see Models 13, A13, B13, and C13), however, the capital liquidity no longer significantly affects the dependent variable. In addition, the results in Model A8 to Model A12 also demonstrate that CEO stock ownerships significantly and positively affect the premiums paid, meaning that CEOs with higher stock ownerships tend to pay higher premiums. Perhaps, CEOs with higher stock ownerships expect their company stock prices to increase following the announcement and the completion of the mergers, and they accordingly can take advantage from capital gains. This finding does not support the prediction formulated.

In Model A13, in addition to the timing of mergers and the CEO stock ownerships, the pre-merger sales growth also explains the amount of premiums paid: the higher the premerger sales growth, the higher the premiums paid. Nevertheless, in general, pre-merger performance does not affect the premiums paid to target firms. The findings of this study, overall, conclude that the major factors that influence the premiums paid to the targets are the timing of mergers (i.e., merger waves) and capital liquidity (i.e., year of high liquidity). The main independent variable (CEOs' behavior) examined in this study, however, does not exhibit any significant effect on the dependent variable (premiums paid). 
Gadjah Mada International Journal of Business, May-August 2009, Vol. 11, No. 2

\section{Conclusion}

In this study, the tests on the difference in premiums paid by overconfident and less overconfident bidder CEOs, for in-wave and non-wave mergers, for within and across industry mergers, for stock and cash mergers, and for mergers undertaken during a high and low liquidity year have been conducted. This study argues that overconfident CEOs may overestimate the values of target firms, their abilities to manage the targets, or the gains/returns from mergers. As a consequence, their overconfidence may lead them to pay higher premiums to the targets. This study employs three measures of CEOs' behaviour, i.e., Measure A, Measure B, and Measure $\mathrm{C}$, and the results of this study indicate that there is no difference between premiums paid by overconfident and less overconfident CEOs either when Measure A or Measure $C$ is used as a measure of CEOs' behaviour. When Measure B is employed, the difference in premiums paid between the two groups of CEOs is significant but it is the less overconfident CEOs who pay the higher premiums. Regression analysis shows that the effect of CEO overconfidence (gauged using each of the three measures) on the premiums paid to target firms is insignificant.

Bidders that use stocks to finance their mergers are argued to pay higher merger premiums to target firms when their stocks are overvalued. In contrast to this argument, this study finds that bidders of cash mergers pay signifi- cantly more premiums than do bidders of stock mergers. This is more likely due to the undervaluation of bidders' stocks and/or the high level of their free cash flows. Nevertheless, the regression results indicate that the method of payment has no significant effect on the premiums paid to target firms.

It is also argued that the payment of higher premiums may occur especially during merger waves where the competition amongst bidders potentially exists. The finding of univariate tests in this study, however, shows that there is no difference between premiums paid for in-wave and non-wave mergers. On the other hand, the results of multivariate tests (in all models employed) demonstrate that bidders that undertake mergers during merger waves pay higher merger premiums. The other argument of this study is that in the year of high capital liquidity, bidders tend to pay higher premiums as the transaction costs are low. This argument is confirmed by both univariate and multivariate tests conducted. These results suggest that bidders pay higher premiums when they have access to economic sources of fund to accommodate the reallocation of assets.

Although the result of univariate tests does not show a significant difference in premiums paid for mergers that occur during merger waves and outside the waves, the timing of merger remains an important variable that must be critically considered since it has a significant effect on the premiums paid 


\section{Soegiharto-What Drives the Payment of Higher Merger Premiums?}

to target firms when combined with one or more other independent variables in regression models. In this study, the timing of merger (i.e., merger waves) and capital liquidity (i.e., year of high liquidity) are variables that significantly and positively affect the premiums paid to target firms. On the other hand, the main independent variable (CEOs' behaviour) examined in this study, in general, does not show any significant effect on the premiums paid. There is a doubt as to whether the CEO overconfidence is “exaggerated”.

The other results of univariate tests indicate that premiums paid by overconfident CEOs for mergers undertaken during merger waves and out- side the waves are not significantly different. This may occuras — although there may be a potential competition amongst interested bidders - the presence of many targets during merger waves may provide an opportunity for overconfident bidder CEOs to choose the most favorable one without paying higher premiums. In addition, the results show that the premiums paid by overconfident CEOs and less overconfident CEOs during merger waves are not significantly different. Also, irrespective of CEOs' behaviour, the premiums paid by bidder CEOs during merger waves and outside the waves are not significantly different.

\section{References}

Alicke, M. D. 1985. Global self-evaluation as determined by the desirability and controllability of trait Adjectives. Journal of Personality and Social Psychology 49: 16211630.

Alicke, M. D., M. L. Klotz, D. L. Breitenbecher, and T. J. Yurak. 1995. Personal contact, individuation, and the better-than-average effect. Journal of Personality and Social Psychology 68 (5): 804-825.

Andrade, G., M. Mitchell, and E. Safford. 2001. New evidence and perspectives on mergers. Journal of Economic Perpectives 15 (2): 103-120.

Andrade, G., and E. Stafford. 2004. Investigating the economic role of mergers. Journal of Corporate Finance 10 (1): 1-36.

Ang, J. S., and Y. Cheng. 2003. Direct evidence on the market-driven acquisitions theory. Working Paper. Florida State University.

Asquith, P., and D. Mullins. 1986. Equity issues and offering dilution. Journal of Financial Economics (January/February): 61-89.

Berger, P. G., and E. Ofek. 1995. Diversification's effect on firm value. Journal of Financial Economics 37 (1): 39-65.

Bradley, M., A. Desay, and E. Kim. 1988. Synergistic gains and their division between the stockholders of target and acquiring firms. Journal of Financial Economics 21 (May): 3-40. 
Comment, R., and G. A. Jarrell. 1995. Corporate focus and stock returns. Journal of Financial Economics 37: 67-87.

Crawford, D., and T. A. Lechner. 1996. Takeover premiums and anticipated merger gains in the US market for corporate control. Journal of Business Finance and Accounting 23 (5-6): 807-830.

Dong, M., D. Hirshleifer, S. Richardson, and S. H. Teoh. 2002. Does investor misvaluation drive the takeover market? Working Paper. Ohio State University.

Fama, E., and K. French. 1997. Industry costs of equity. Journal of Financial Economics 43: 153-193.

Finkelstein, S., and D. C. Hambrick. 1989. Chief executive compensation: A study of the intersection of markets and political processes. Strategic Management Journal 10 (2): 121-134.

Frank, J. R., R. S. Harris, and S. Titman. 1991. The post-merger share price performance of acquiring firms. Journal of Financial Economics 29: 81-96.

Gervais, S., and T. Odean. 2001. Learning to be overconfident. Review of Financial Studies 14 (1): 1-27.

Harford, J. 2005. What drives merger waves? Journal of Financial Economics 77: 529560.

Haspeslagh, P. C., D. B. and Jemison. 1991. Managing acquisitions:Creating Value through Corporate Renewal. New York: Free Press.

Hayward, M. L. A., and D. C. Hambrick. 1997. Explaining the premium paid for large acquisitions: Evidence of CEO hubris. Administrative Science Quarterly 42 (1): 103127.

Hietala, P., S. N. Kaplan, and D. T. Robinson. 2003. What is the price of hubris? Using takeover battles to infer overpayments and synergies. Financial Management 32 (3).

Hubbard, R. G., and D. Palia. 1999. A reexamination of the conglomerate merger wave in the 1960s: An internal capital markets view. The Journal of Finance LIV (3): 11311152.

Lang, L. H. P., and R. M. Stulz. 1994. Tobin's q, corporate diversification, and firm performance. The Journal of Political Economy 102 (6): 1248-1280.

Langer, E. J. 1975. The Illusion of control. Journal of Personality and Social Psychology 32: 311-328.

Mace, M. 1971. Directors: Myth and Reality. Boston: Harvard Business School Press.

Malmendier, U., and G. Tate. 2003. Who makes acquisitions? CEO overconfidence and the market's reaction. Working Paper.

March, J. G., and Z. Shapira. 1987. Managerial perspectives on risk and risk taking. Management Science 33: 1404-1418.

Masulis, R., and A. Korwar. 1986. Seasoned equity offerings: An empirical investigation. Journal of Financial Economics (January/February): 91-118.

Matsusaka, J. G. 1993. Takeover motives during the conglomerate merger wave. RAND Journal of Economics 24 (3) (Autumn): 357-379. 
Soegiharto-What Drives the Payment of Higher Merger Premiums?

Mikkelson, W., and M. Partch. 1986. Valuation effects on security offerings and the issuance process. Journal of Financial Economics (January/February): 31-60.

Mitchell, M. L., and H. J. Mulherin. 1996. The impact of industry shocks on takeover and restructuring activity. Journal of Financial Economics 41 (2): 193-229.

Morck, R., A. Shleifer, A., and R. W. Vishny. 1990. Do managerial objectives drive bad acquisitions? The Journal of Finance XLV (1): 31-48.

Mulherin, J. H., and A. L. Boone. 2000. Comparing acquisitions and divestitures. Journal of Corporate Finance 6: 117-139.

Myers, S. C., and N. S. Majluf. 1984. Corporate financing and investment decisions when firms have information that investors do not have. Journal of Financial Economics 13: 187-221.

Raj, M., and M. Forsyth. 2003. Hubris amongst U.K. bidders and losses to shareholders International Journal of Business 8 (1): 1-16.

Rhodes-Kropf, M., D. T. Robinson, and S. Viswanathan. 2004. Valuation waves and merger activity: The empirical evidence. Working Paper. Columbia University.

Rhodes-Kropf, M., and S. Viswanathan. 2004. Market valuation and merger waves. Journal of Finance 59 (6): 2685-2718.

Roll, R. 1986. The hubris hypothesis of corporate takeovers. The Journal of Business 59 (2): 197-216.

Rose, N., and A. Shepard. 1997. Firm diversification and CEO compensation: Managerial ability or executive entrenchment? The Rand Journal of Economics 28: 489-514.

Servaes, H. 1991. Tobin's Q and the gains from takeovers. Journal of Finance 46: 409419.

Shleifer, A., and R. Vishny. 1989. Management entrenchment: The case of managerspecific investments. Journal of Financial Economics 25: 123 - 139.

Shleifer, A., and. W. Vishny. 2003. Stock market driven acquisitons. Journal of Financial Economics 70 (3): 295-311.

Soegiharto, S. 2008. Drivers of merger waves: A revisit. Gadjah Mada International Journal of Business 10 (1): 1-23.

Travlos, N. G. 1987. Corporate takeover bids, methods of payment, and bidding firms' stock return. The Journal of Finance 42 (4): 943-963.

Weinstein, N. D. 1980. Unrealistic optimism about future life events. Journal of Personality and Social Psychology 39: 806-820.

Weinstein, N. D., and W. M. Klein. 2002. Resistance of personal risk perceptions to debiasing interventions. In T. Gilovich, D. Griffin, and D. Kahneman (eds.) Heuristics and Biases: The Psychology of Intuitive Judgment. Cambridge, UK: Cambridge University Press: 313-323. 
Gadjah Mada International Journal of Business, May-August 2009, Vol. 11, No. 2

\section{Appendix A. Predicting Premiums Paid to Targets Using Individual Predictors}

Bid premiums are calculated as: (bid offer - target price ${ }_{30}$ )/target price ${ }_{30}$. Bid offer is the final price paid per target share by the bidder and target price $_{-30}$ is the value of the target shares thirty days prior to the first bid announcement. The explanatory variables employed in the regression analyses are free cash flows, leverage, CEOs tenure, and CEOs stock ownerships. Free cash flow is calculated as operating income - (taxes + interest + preferred dividend + common dividend) and leverage is calculated as long-term debt divided by book value of equities. The difference between the date an individual became a $\mathrm{CEO}$ and the date the mergers announced is used to determine $\mathrm{CEO}$ s' tenure, and shares owned by $\mathrm{CEO}$ s is divided by number of shares outstanding to obtain CEOs' stock ownerships. The measure of performance used as predictors are net income to sales, assets turnover, return on assets, sales growth, and market-to-book. Five other explanatory variables are dummies. These variables are method of payment that takes value of 1 for stock and 0 for cash, capital liquidity that takes value of 1 for high liquidity years (the years in which the rate spread is below its time-series median and the industry's market-to-book ratio is simultaneously above its time-series median) and 0 for low liquidity year (all other years), timing of merger that takes value of 1 for waved merger and 0 for non-waved merger, industry of merged firms that takes value of 1 for intra-industry mergers and 0 for inter-industry mergers, and CEOs behaviour that takes value of 1 for overconfident CEOs and 0 for less overconfident CEOs. Three measures of CEOs' behaviour, Measure A, Measure B, and Measure C, are used in Model A, Model B, and Model C, respectively.

\begin{tabular}{|c|c|c|c|c|c|c|c|c|}
\hline & 1 & 2 & 3 & 4 & 5 & 6 & 7 & 8 \\
\hline Intercept & $\begin{array}{c}0.513 \\
{[0.000]}\end{array}$ & $\begin{array}{c}0.496 \\
{[0.000]}\end{array}$ & $\begin{array}{c}0.532 \\
{[0.000]}\end{array}$ & $\begin{array}{c}0.454 \\
{[0.000]}\end{array}$ & $\begin{array}{c}0.475 \\
{[0.000]}\end{array}$ & $\begin{array}{c}0.465 \\
{[0.000]}\end{array}$ & $\begin{array}{c}0.463 \\
{[0.000]}\end{array}$ & $\begin{array}{c}0.479 \\
{[0.000]}\end{array}$ \\
\hline Pre-merger FCF & $\begin{array}{c}0.000 \\
{[0.816]}\end{array}$ & & & & & & & \\
\hline Pre-merger Leverage & & $\begin{array}{c}-0.056 \\
{[0.418]}\end{array}$ & & & & & & \\
\hline Method of Payment & & & $\begin{array}{c}-0.100 \\
{[0.034]}\end{array}$ & & & & & \\
\hline Capital Liquidity & & & & $\begin{array}{c}0.081 \\
{[0.069]}\end{array}$ & & & & \\
\hline Timing of Mergers & & & & & $\begin{array}{c}0.011 \\
{[0.792]}\end{array}$ & & & \\
\hline Industry of Merged Firms & & & & & & $\begin{array}{l}-0.007 \\
{[0.858]}\end{array}$ & & \\
\hline CEOs Tenure & & & & & & & $\begin{array}{c}0.000 \\
{[0.660]}\end{array}$ & \\
\hline CEOs Stock Ownerships & & & & & & & & $\begin{array}{r}-0.080 \\
{[0.604]}\end{array}$ \\
\hline Adjusted $\mathrm{R}^{2}$ & -0.006 & -0.001 & 0.019 & 0.010 & -0.004 & -0.004 & -0.003 & -0.004 \\
\hline Std. Error of the Estimate & 0.310 & 0.311 & 0.298 & 0.298 & 0.305 & 0.295 & 0.312 & 0.316 \\
\hline $\mathrm{p}$-value for F-test & 0.816 & 0.418 & 0.034 & 0.069 & 0.792 & 0.858 & 0.660 & 0.604 \\
\hline Number of observations & 172 & 228 & 180 & 224 & 263 & 259 & 260 & 194 \\
\hline
\end{tabular}


Soegiharto-What Drives the Payment of Higher Merger Premiums?

\section{Continued from Appendix A}

\begin{tabular}{|c|c|c|c|c|c|c|c|c|}
\hline & 9 & 10 & 11 & 12 & 13 & 14 & 15 & 16 \\
\hline Intercept & $\begin{array}{c}0.497 \\
{[0.000]}\end{array}$ & $\begin{array}{c}0.476 \\
{[0.000]}\end{array}$ & $\begin{array}{c}0.495 \\
{[0.000]}\end{array}$ & $\begin{array}{c}0.466 \\
{[0.000]}\end{array}$ & $\begin{array}{c}0.461 \\
{[0.000]}\end{array}$ & $\begin{array}{c}0.487 \\
{[0.000]}\end{array}$ & $\begin{array}{c}0.549 \\
{[0.000]}\end{array}$ & $\begin{array}{c}0.493 \\
{[0.000]}\end{array}$ \\
\hline Pre-merger Net Income/Sales & $\begin{array}{c}-0.317 \\
{[0.259]}\end{array}$ & & & & & & & \\
\hline Pre-merger Assets Turnover & & $\begin{array}{c}0.011 \\
{[0.817]}\end{array}$ & & & & & & \\
\hline Pre-merger Return on Assets & & & $\begin{array}{c}-0.179 \\
{[0.231]}\end{array}$ & & & & & \\
\hline Pre-merger Sales Growth & & & & $\begin{array}{c}0.092 \\
{[0.414]}\end{array}$ & & & & \\
\hline Pre-merger Market-to-Book ratio & & & & & $\begin{array}{c}0.015 \\
{[0.107]}\end{array}$ & & & \\
\hline CEOs' Behaviour (Measure A) & & & & & & $\begin{array}{c}-0.027 \\
{[0.508]}\end{array}$ & & \\
\hline CEOs’ Behaviour (Measure B) & & & & & & & $\begin{array}{c}-0.119 \\
{[0.002]}\end{array}$ & \\
\hline CEOs’ Behaviour (Measure C) & & & & & & & & $\begin{array}{c}-0.046 \\
{[0.208]}\end{array}$ \\
\hline Adjusted $R^{2}$ & 0.001 & -0.004 & 0.002 & -0.001 & 0.007 & -0.002 & 0.032 & 0.002 \\
\hline Std. Error of the Estimate & 0.307 & 0.312 & 0.304 & 0.302 & 0.307 & 0.300 & 0.288 & 0.295 \\
\hline$p$-value for $F$-test & 0.259 & 0.817 & 0.231 & 0.414 & 0.107 & 0.508 & 0.002 & 0.208 \\
\hline Number of observations & 233 & 252 & 249 & 238 & 247 & 228 & 259 & 260 \\
\hline
\end{tabular}


Gadjah Mada International Journal of Business, May-August 2009, Vol. 11, No. 2

\title{
Appendix B. Predicting Premiums Paid to Targets Using the Combination of Each of Measures of CEOs Behaviour and the Other Individual Predictors Employed
}

\begin{abstract}
Bid premiums are calculated as: (bid offer - target price ${ }_{30} /$ target price ${ }_{30}$. Bid offer is the final price paid per target share by the bidder and target price $_{-30}$ is the value of the target shares thirty days prior to the first bid announcement. The explanatory variables employed in the regression analyses are free cash flows, leverage, CEOs tenure, and CEOs stock ownerships. Free cash flow is calculated as operating income - (taxes + interest + preferred dividend + common dividend) and leverage is calculated as long-term debt divided by book value of equities. The difference between the date an individual became a $\mathrm{CEO}$ and the date the mergers announced is used to determine CEOs' tenure, and shares owned by CEOs is divided by number of shares outstanding to obtain CEOs' stock ownerships. The measure of performance used as predictors are net income to sales, assets turnover, return on assets, sales growth, and market-to-book. Five other explanatory variables are dummies. These variables are method of payment that takes value of 1 for stock and 0 for cash, capital liquidity that takes value of 1 for high liquidity years (the years in which the rate spread is below its time-series median and the industry's market-to-book ratio is simultaneously above its time-series median) and 0 for low liquidity year (all other years), timing of merger that takes value of 1 for waved merger and 0 for non-waved merger, industry of merged firms that takes value of 1 for intra-industry mergers and 0 for inter-industry mergers, and CEOs behaviour that takes value of 1 for overconfident CEOs and 0 for less overconfident CEOs. Three measures of CEOs' behaviour, Measure A, Measure B, and Measure C, are used in Model A, Model B, and Model C, respectively.
\end{abstract}

\begin{tabular}{|c|c|c|c|c|c|c|c|c|}
\hline & \multicolumn{8}{|c|}{ With Measure A (Model A) } \\
\hline & A1 & A2 & A3 & A4 & A5 & A6 & A7 & A8 \\
\hline Intercept & $\begin{array}{c}0.528 \\
{[0.000]}\end{array}$ & $\begin{array}{c}0.489 \\
{[0.000]}\end{array}$ & $\begin{array}{c}0.529 \\
{[0.000]}\end{array}$ & $\begin{array}{c}0.500 \\
{[0.000]}\end{array}$ & $\begin{array}{c}0.478 \\
{[0.000]}\end{array}$ & $\begin{array}{c}0.466 \\
{[0.000]}\end{array}$ & $\begin{array}{c}0.454 \\
{[0.000]}\end{array}$ & $\begin{array}{c}0.491 \\
{[0.000]}\end{array}$ \\
\hline Pre-merger FCF & $\begin{array}{c}0.000 \\
{[0.856]}\end{array}$ & & & & & & & \\
\hline Pre-merger Leverage & & $\begin{array}{c}-0.046 \\
{[0.529]}\end{array}$ & & & & & & \\
\hline Method of Payment & & & $\begin{array}{c}-0.078 \\
{[0.127]}\end{array}$ & & & & & \\
\hline Capital Liquidity & & & & $\begin{array}{c}0.069 \\
{[0.147]}\end{array}$ & & & & \\
\hline Timing of Mergers & & & & & $\begin{array}{c}0.021 \\
{[0.616]}\end{array}$ & & & \\
\hline Firms Industry & & & & & & $\begin{array}{c}0.024 \\
{[0.543]}\end{array}$ & & \\
\hline CEOs Tenure & & & & & & & $\begin{array}{c}0.000 \\
{[0.415]}\end{array}$ & \\
\hline CEOs Ownerships & & & & & & & & $\begin{array}{c}-0.095 \\
{[0.462]}\end{array}$ \\
\hline CEOs' Behaviour & $\begin{array}{c}-0.046 \\
{[0.380]}\end{array}$ & $\begin{array}{c}0.008 \\
{[0.851]}\end{array}$ & $\begin{array}{c}-0.019 \\
{[0.700]}\end{array}$ & $\begin{array}{c}-0.088 \\
{[0.045]}\end{array}$ & $\begin{array}{c}-0.024 \\
{[0.573]}\end{array}$ & $\begin{array}{c}-0.036 \\
{[0.365]}\end{array}$ & $\begin{array}{c}-0.005 \\
{[0.902]}\end{array}$ & $\begin{array}{c}-0.013 \\
{[0.789]}\end{array}$ \\
\hline Adjusted $R^{2}$ & -0.008 & -0.008 & 0.003 & 0.020 & -0.006 & -0.004 & -0.006 & -0.008 \\
\hline SE of the Estimate & 0.311 & 0.310 & 0.303 & 0.290 & 0.300 & 0.286 & 0.313 & 0.317 \\
\hline$p$-value for $F$-test & 0.676 & 0.811 & 0.286 & 0.054 & 0.708 & 0.576 & 0.711 & 0.753 \\
\hline Number of observations & 148 & 205 & 157 & 193 & 228 & 224 & 230 & 186 \\
\hline
\end{tabular}

224 
Soegiharto-What Drives the Payment of Higher Merger Premiums?

\section{Continued from Appendix B}

\begin{tabular}{|c|c|c|c|c|c|c|c|c|}
\hline & \multicolumn{8}{|c|}{ With Measure B (Model B) } \\
\hline & B1 & B2 & B3 & B4 & B5 & B6 & B7 & B8 \\
\hline Intercept & $\begin{array}{c}0.555 \\
{[0.000]}\end{array}$ & $\begin{array}{c}0.576 \\
{[0.000]}\end{array}$ & $\begin{array}{c}0.582 \\
{[0.000]}\end{array}$ & $\begin{array}{c}0.535 \\
{[0.000]}\end{array}$ & $\begin{array}{c}0.524 \\
{[0.000]}\end{array}$ & $\begin{array}{c}0.527 \\
{[0.000]}\end{array}$ & $\begin{array}{c}0.540 \\
{[0.000]}\end{array}$ & $\begin{array}{c}0.550 \\
{[0.000]}\end{array}$ \\
\hline Pre-merger FCF & $\begin{array}{c}0.000 \\
{[0.878]}\end{array}$ & & & & & & & \\
\hline Pre-merger Leverage & & $\begin{array}{c}-0.043 \\
{[0.524]}\end{array}$ & & & & & & \\
\hline Method of Payment & & & $\begin{array}{c}-0.066 \\
{[0.148]}\end{array}$ & & & & & \\
\hline Capital Liquidity & & & & $\begin{array}{c}0.057 \\
{[0.191]}\end{array}$ & & & & \\
\hline Timing of Mergers & & & & & $\begin{array}{c}0.023 \\
{[0.541]}\end{array}$ & & & \\
\hline Firms Industry & & & & & & $\begin{array}{c}-0.006 \\
{[0.860]}\end{array}$ & & \\
\hline CEOs Tenure & & & & & & & $\begin{array}{c}0.000 \\
{[0.770]}\end{array}$ & \\
\hline CEOs Ownerships & & & & & & & & $\begin{array}{c}-0.004 \\
{[0.975]}\end{array}$ \\
\hline CEOs' Behaviour & $\begin{array}{c}-0.067 \\
{[0.180]}\end{array}$ & $\begin{array}{c}-0.118 \\
{[0.009]}\end{array}$ & $\begin{array}{c}-0.115 \\
{[0.014]}\end{array}$ & $\begin{array}{c}-0.114 \\
{[0.007]}\end{array}$ & $\begin{array}{c}-0.101 \\
{[0.009]}\end{array}$ & $\begin{array}{c}-0.094 \\
{[0.015]}\end{array}$ & $\begin{array}{c}-0.104 \\
{[0.012]}\end{array}$ & $\begin{array}{c}-0.107 \\
{[0.035]}\end{array}$ \\
\hline Adjusted $R^{2}$ & -0.001 & 0.024 & 0.038 & 0.034 & 0.021 & 0.015 & 0.017 & 0.012 \\
\hline SE of the Estimate & 0.309 & 0.307 & 0.286 & 0.291 & 0.283 & 0.281 & 0.307 & 0.313 \\
\hline$p$-value for F-test & 0.395 & 0.023 & 0.013 & 0.008 & 0.026 & 0.051 & 0.039 & 0.109 \\
\hline Number of observations & 172 & 228 & 178 & 223 & 257 & 256 & 263 & 200 \\
\hline
\end{tabular}


Gadjah Mada International Journal of Business, May-August 2009, Vol. 11, No. 2

\section{Continued from Appendix B}

\begin{tabular}{|c|c|c|c|c|c|c|c|c|}
\hline & \multicolumn{8}{|c|}{ With Measure C (Model C) } \\
\hline & $\mathrm{C} 1$ & $\mathrm{C} 2$ & $\mathrm{C} 3$ & $\mathrm{C} 4$ & $\mathrm{C} 5$ & $\mathrm{C} 6$ & $\mathrm{C} 7$ & $\mathrm{C} 8$ \\
\hline Intercept & $\begin{array}{c}0.565 \\
{[0.000]}\end{array}$ & $\begin{array}{c}0.491 \\
{[0.000]}\end{array}$ & $\begin{array}{c}0.538 \\
{[0.000]}\end{array}$ & $\begin{array}{c}0.485 \\
{[0.000]}\end{array}$ & $\begin{array}{c}0.478 \\
{[0.000]}\end{array}$ & $\begin{array}{c}0.481 \\
{[0.000]}\end{array}$ & $\begin{array}{c}0.474 \\
{[0.000]}\end{array}$ & $\begin{array}{c}0.484 \\
{[0.000]}\end{array}$ \\
\hline Pre-merger FCF & $\begin{array}{c}0.000 \\
{[0.761]}\end{array}$ & & & & & & & \\
\hline Pre-merger Leverage & & $\begin{array}{c}-0.055 \\
{[0.427]}\end{array}$ & & & & & & \\
\hline Method of Payment & & & $\begin{array}{c}-0.089 \\
{[0.058]}\end{array}$ & & & & & \\
\hline Capital Liquidity & & & & $\begin{array}{c}0.062 \\
{[0.158]}\end{array}$ & & & & \\
\hline Timing of Mergers & & & & & $\begin{array}{c}0.028 \\
{[0.472]}\end{array}$ & & & \\
\hline Firms Industry & & & & & & $\begin{array}{c}0.001 \\
{[0.984]}\end{array}$ & & \\
\hline CEOs Tenure & & & & & & & $\begin{array}{c}0.000 \\
{[0.665]}\end{array}$ & \\
\hline CEOs Ownerships & & & & & & & & $\begin{array}{c}-0.073 \\
{[0.580]}\end{array}$ \\
\hline CEOs' Behaviour & $\begin{array}{c}-0.099 \\
{[0.036]}\end{array}$ & $\begin{array}{c}0.010 \\
{[0.817]}\end{array}$ & $\begin{array}{c}-0.031 \\
{[0.479]}\end{array}$ & $\begin{array}{l}-0.060 \\
{[0.129]}\end{array}$ & $\begin{array}{c}-0.040 \\
{[0.265]}\end{array}$ & $\begin{array}{c}-0.046 \\
{[0.191]}\end{array}$ & $\begin{array}{c}-0.021 \\
{[0.585]}\end{array}$ & $\begin{array}{c}-0.013 \\
{[0.774]}\end{array}$ \\
\hline Adjusted $R^{2}$ & 0.015 & -0.006 & 0.012 & 0.013 & -0.001 & -0.001 & -0.006 & -0.008 \\
\hline SE of the Estimate & 0.307 & 0.312 & 0.294 & 0.294 & 0.292 & 0.283 & 0.311 & 0.314 \\
\hline$p$-value for $F$-test & 0.106 & 0.701 & 0.132 & 0.091 & 0.417 & 0.425 & 0.799 & 0.803 \\
\hline Number of observations & 172 & 228 & 179 & 223 & 259 & 256 & 262 & 199 \\
\hline
\end{tabular}


Soegiharto—What Drives the Payment of Higher Merger Premiums?

\section{Appendix C. Predicting Premium Paid to Targets Using the Combination of Each of Measures of CEOs' Behaviour and Each of Groups of Predictors Classified}

The predictors employed in the regression analyses are classified into four groups: accounting numbers factors group that consist of free cash flows and leverage, financing factors group that consist of method of payment and capital liquidity, merger factors group that comprise the timing of mergers and the industry of merged firms, and CEOs factors group that contain CEOs tenure and CEOs stock ownerships. Bid premiums are calculated as: (bid offer-target price ${ }_{-30}$ )/target price ${ }_{-30^{\circ}}$. Bid offer is the final price paid per target share by the bidder and target price ${ }_{-30}$ is the value of the target shares thirty days prior to the first bid announcement. The explanatory variables employed in the regression analyses are free cash flows, leverage, CEOs tenure, and CEOs stock ownerships. Free cash flow is calculated as operating income - (taxes + interest + preferred dividend + common dividend) and leverage is calculated as long-term debt divided by book value of equities. The difference between the date an individual became a CEO and the date the mergers announced is used to determine CEOs' tenure, and shares owned by CEOs is divided by number of shares outstanding to obtain CEOs' stock ownerships. The measure of performance used as predictors are net income to sales, assets turnover, return on assets, sales growth, and market-to-book. Five other explanatory variables are dummies. These variables are method of payment that takes value of 1 for stock and 0 for cash, capital liquidity that takes value of 1 for high liquidity years (the years in which the rate spread is below its time-series median and industry's market-to-book ratio is simultaneously above its time-series median) and 0 for low liquidity year (all other years), timing of merger that takes value of 1 for waved merger and 0 for non-waved merger, industry of merged firms that takes value of 1 for intra-industry mergers and 0 for inter-industry mergers, and CEOs behaviour that takes value of 1 for overconfident CEOs and 0 for less overconfident CEOs. Three measures of CEOs' behaviour i.e., Measure A, Measure B, and Measure C are used in Model A, Model B, and Model C, respectively.

\begin{tabular}{|c|c|c|c|c|c|c|c|c|}
\hline & \multicolumn{4}{|c|}{ Without Measure of Behaviour } & \multicolumn{4}{|c|}{ With Measure A (Model A) } \\
\hline & 1 & 2 & 3 & 4 & A1 & $\mathrm{A} 2$ & A3 & A4 \\
\hline Intercept & $\begin{array}{c}0.537 \\
{[0.000]}\end{array}$ & $\begin{array}{c}0.506 \\
{[0.000]}\end{array}$ & $\begin{array}{c}0.463 \\
{[0.000]}\end{array}$ & $\begin{array}{c}0.493 \\
{[0.000]}\end{array}$ & $\begin{array}{c}0.540 \\
{[0.000]}\end{array}$ & $\begin{array}{c}0.539 \\
{[0.000]}\end{array}$ & $\begin{array}{c}0.459 \\
{[0.000]}\end{array}$ & $\begin{array}{c}0.483 \\
{[0.000]}\end{array}$ \\
\hline Pre-merger FCF & $\begin{array}{c}0.000 \\
{[0.939]}\end{array}$ & & & & $\begin{array}{c}0.000 \\
{[0.742]}\end{array}$ & & & \\
\hline Pre-merger Leverage & $\begin{array}{c}-0.071 \\
{[0.407]}\end{array}$ & & & & $\begin{array}{c}-0.063 \\
{[0.132]}\end{array}$ & & & \\
\hline Method of Payment & & $\begin{array}{c}-0.099 \\
{[0.047]}\end{array}$ & & & & $\begin{array}{c}-0.087 \\
{[0.132]}\end{array}$ & & \\
\hline Capital Liquidity & & $\begin{array}{c}0.129 \\
{[0.031]}\end{array}$ & & & & $\begin{array}{c}0.160 \\
{[0.021]}\end{array}$ & & \\
\hline Timing of Mergers & & & $\begin{array}{c}0.011 \\
{[0.768]}\end{array}$ & & & & $\begin{array}{c}-0.003 \\
{[0.952]}\end{array}$ & \\
\hline Firms Industry & & & $\begin{array}{c}-0.009 \\
{[0.811]}\end{array}$ & & & & $\begin{array}{c}0.036 \\
{[0.395]}\end{array}$ & \\
\hline CEOs Tenure & & & & $\begin{array}{c}0.000 \\
{[0.549]}\end{array}$ & & & & $\begin{array}{c}-0.187 \\
{[0.185]}\end{array}$ \\
\hline CEOs Ownerships & & & & $\begin{array}{c}-0.063 \\
{[0.647]}\end{array}$ & & & & $\begin{array}{c}0.000 \\
{[0.651]}\end{array}$ \\
\hline CEOs’ Behaviour & & & & & $\begin{array}{c}-0.023 \\
{[0.669]}\end{array}$ & $\begin{array}{c}-0.070 \\
{[0.213]}\end{array}$ & $\begin{array}{c}-0.010 \\
{[0.823]}\end{array}$ & $\begin{array}{c}-0.005 \\
{[0.913]}\end{array}$ \\
\hline Adjusted $R^{2}$ & -0.009 & 0.044 & -0.007 & -0.006 & -0.017 & 0.047 & -0.010 & -0.007 \\
\hline SE of the Estimate & 0.306 & 0.294 & 0.288 & 0.312 & 0.303 & 0.319 & 0.313 & 0.314 \\
\hline$p$-value for F-test & 0.709 & 0.012 & 0.936 & 0.655 & 0.848 & 0.025 & 0.861 & 0.622 \\
\hline Number of observations & 146 & 153 & 257 & 198 & 129 & 136 & 231 & 185 \\
\hline
\end{tabular}


Gadjah Mada International Journal of Business, May-August 2009, Vol. 11, No. 2

\section{Continous from Appendix C}

\begin{tabular}{|c|c|c|c|c|c|c|c|c|}
\hline & \multicolumn{4}{|c|}{ With Measure B (Model B) } & \multicolumn{4}{|c|}{ With Measure C (Model C) } \\
\hline & B1 & B2 & B3 & B4 & $\mathrm{C} 1$ & $\mathrm{C} 2$ & $\mathrm{C} 3$ & $\mathrm{C} 4$ \\
\hline Intercept & $\begin{array}{c}0.564 \\
{[0.000]}\end{array}$ & $\begin{array}{c}0.565 \\
{[0.000]}\end{array}$ & $\begin{array}{c}0.544 \\
{[0.000]}\end{array}$ & $\begin{array}{c}0.561 \\
{[0.000]}\end{array}$ & $\begin{array}{c}0.579 \\
{[0.000]}\end{array}$ & $\begin{array}{c}0.523 \\
{[0.000]}\end{array}$ & $\begin{array}{c}0.476 \\
{[0.000]}\end{array}$ & $\begin{array}{c}0.487 \\
{[0.000]}\end{array}$ \\
\hline Pre-merger FCF & $\begin{array}{c}0.000 \\
{[0.899]}\end{array}$ & & & & $\begin{array}{c}0.000 \\
{[0.990]}\end{array}$ & & & \\
\hline Pre-merger Leverage & $\begin{array}{c}-0.060 \\
{[0.483]}\end{array}$ & & & & $\begin{array}{c}-0.070 \\
{[0.407]}\end{array}$ & & & \\
\hline Method of Payment & & $\begin{array}{c}-0.086 \\
{[0.098]}\end{array}$ & & & & $\begin{array}{c}-0.095 \\
{[0.070]}\end{array}$ & & \\
\hline Capital Liquidity & & $\begin{array}{c}0.143 \\
{[0.020]}\end{array}$ & & & & $\begin{array}{c}0.146 \\
{[0.019]}\end{array}$ & & \\
\hline Timing of Mergers & & & $\begin{array}{c}0.000 \\
{[0.993]}\end{array}$ & & & & $\begin{array}{c}-0.002 \\
{[0.959]}\end{array}$ & \\
\hline Firms Industry & & & $\begin{array}{c}0.008 \\
{[0.828]}\end{array}$ & & & & $\begin{array}{c}0.018 \\
{[0.655]}\end{array}$ & \\
\hline CEOs Tenure & & & & $\begin{array}{c}0.005 \\
{[0.971]}\end{array}$ & & & & $\begin{array}{c}-0.073 \\
{[0.589]}\end{array}$ \\
\hline CEOs Ownerships & & & & $\begin{array}{c}0.000 \\
{[0.408]}\end{array}$ & & & & $\begin{array}{c}0.000 \\
{[0.929]}\end{array}$ \\
\hline CEOs' Behaviour & $\begin{array}{c}-0.046 \\
{[0.387]}\end{array}$ & $\begin{array}{l}-0.099 \\
{[0.062]}\end{array}$ & $\begin{array}{c}-0.106 \\
{[0.011]}\end{array}$ & $\begin{array}{l}-0.094 \\
{[0.065]}\end{array}$ & $\begin{array}{c}-0.077] \\
{[0.129}\end{array}$ & $\begin{array}{l}-0.040] \\
{[0.422}\end{array}$ & $\begin{array}{c}-0.022] \\
{[0.567}\end{array}$ & $\begin{array}{c}-0.013 \\
{[0.775]}\end{array}$ \\
\hline Adjusted $R^{2}$ & -0.011 & 0.062 & 0.014 & 0.006 & 0.000 & 0.044 & -0.009 & -0.013 \\
\hline SE of the Estimate & 0.306 & 0.306 & 0.307 & 0.312 & 0.305 & 0.309 & 0.311 & 0.314 \\
\hline$p$-value for F-test & 0.696 & 0.005 & 0.080 & 0.237 & 0.390 & 0.020 & 0.915 & 0.914 \\
\hline Number of observations & 146 & 156 & 264 & 200 & 146 & 156 & 264 & 200 \\
\hline
\end{tabular}

